Published in final edited form as:

JMed Chem. 2021 November 25; 64(22): 16731-16745. doi:10.1021/acs.jmedchem.1c01562.

\title{
Synthesis and Screening in Mice of Fluorine-Containing PET Radioligands for TSPO: Discovery of a Promising ${ }^{18}$ F-Labeled Ligand
}

\author{
Fabrice G. Siméon, \\ Molecular Imaging Branch, National Institute of Mental Health, National Institutes of Health, \\ Bethesda, Maryland 20892, United States \\ Jae-Hoon Lee, \\ Molecular Imaging Branch, National Institute of Mental Health, National Institutes of Health, \\ Bethesda, Maryland 20892, United States; Department of Nuclear Medicine, Gangnam \\ Severance Hospital, Yonsei University College of Medicine, Seoul 03772, South Korea \\ Cheryl L. Morse, \\ Molecular Imaging Branch, National Institute of Mental Health, National Institutes of Health, \\ Bethesda, Maryland 20892, United States

\section{lan Stukes,} \\ Molecular Imaging Branch, National Institute of Mental Health, National Institutes of Health, \\ Bethesda, Maryland 20892, United States
}

\section{Sami S. Zoghbi,}

Molecular Imaging Branch, National Institute of Mental Health, National Institutes of Health, Bethesda, Maryland 20892, United States

\section{Lester S. Manly,}

Molecular Imaging Branch, National Institute of Mental Health, National Institutes of Health, Bethesda, Maryland 20892, United States

\section{Jeih-San Liow,}

Molecular Imaging Branch, National Institute of Mental Health, National Institutes of Health, Bethesda, Maryland 20892, United States

\section{Robert L. Gladding,}

\footnotetext{
Corresponding Author Victor W. Pike - Molecular Imaging Branch, National Institute of Mental Health, National Institutes of Health, Bethesda, Maryland 20892, United States; Phone: +1 301594 5986; pikev@ mail.nih.gov.

Author Contributions

F.G.S.: chemistry and radiosynthesis; I.S.: chemistry; C.L.M.: radiosynthesis and analysis; S.T., B.C., C.M., F.D.S., and S.C.: in vitro pharmacology; J.-H.L., J.-S.L., R.L.G., X.Y., and R.M.D.: PET imaging and data analysis; S.S.Z. and L.S.M.: $\log D$ and free fraction determinations; V.W.P. and R.B.I.: project supervision; V.W.P.: project conception. All authors contributed to the writing of this manuscript (overseen by F.G.S. and V.W.P.).

Supporting Information

The Supporting Information is available free of charge at https://pubs.acs.org/doi/10.1021/acs.jmedchem.1c01562.

Plasma free fractions; binding assay results; NMR spectra; chromatograms for radioligand separations and analyses; Molecular

Formula Strings; and mouse PET parameters (PDF)

Compounds' CSV files (CSV)

The authors declare no competing financial interest.
} 
Molecular Imaging Branch, National Institute of Mental Health, National Institutes of Health, Bethesda, Maryland 20892, United States

Rachel M. Dick,

Molecular Imaging Branch, National Institute of Mental Health, National Institutes of Health, Bethesda, Maryland 20892, United States

Xuefeng Yan,

Molecular Imaging Branch, National Institute of Mental Health, National Institutes of Health, Bethesda, Maryland 20892, United States

Sabrina Taliani, Department of Pharmacy, University of Pisa, 56126 Pisa, Italy

Barbara Costa, Department of Pharmacy, University of Pisa, 56126 Pisa, Italy

Claudia Martini, Department of Pharmacy, University of Pisa, 56126 Pisa, Italy

Federico Da Settimo, Department of Pharmacy, University of Pisa, 56126 Pisa, Italy

Sabrina Castellano, Department of Pharmacy, University of Salerno, 84084 Fisciano, SA, Italy

Robert B. Innis,

Molecular Imaging Branch, National Institute of Mental Health, National Institutes of Health, Bethesda, Maryland 20892, United States

Victor W. Pike

Molecular Imaging Branch, National Institute of Mental Health, National Institutes of Health, Bethesda, Maryland 20892, United States

\section{Abstract}

Translocator protein $18 \mathrm{kDa}$ (TSPO) is a biomarker of neuroinflammation. $\left[{ }^{11} \mathrm{C}\right] \mathrm{ER} 176$ robustly quantifies TSPO in the human brain with positron emission tomography (PET), irrespective of subject genotype. We aimed to develop an ER176 analog with potential for labeling with longer-lived fluorine-18 $\left(t_{1 / 2}=109.8 \mathrm{~min}\right)$. New fluoro and trifluoromethyl analogs of ER176 were prepared through a concise synthetic strategy. These ligands showed high TSPO affinity and low human genotype sensitivity. Each ligand was initially labeled by a generic ${ }^{11} \mathrm{C}$-methylation procedure, thereby enabling speedy screening in mice. Each radioligand was rapidly taken up and well retained in the mouse brain at baseline after intravenous injection. Preblocking of TSPO showed that high proportions of brain uptake were specifically bound to TSPO at baseline. Overall, the 3-fluoro analog of $\left[{ }^{11} \mathrm{C}\right] \mathrm{ER} 176\left(\left[{ }^{11} \mathrm{C}\right] \mathbf{3 b}\right)$ displayed the most promising imaging properties. Therefore, a method was developed to label $\mathbf{3 b}$ with $\left[{ }^{18} \mathrm{~F}\right]$ fluoride ion. $\left[{ }^{18} \mathrm{~F}\right] \mathbf{3 b}$ gave similarly promising PET imaging results and deserves evaluation in higher species.

\section{Graphical Abstract}



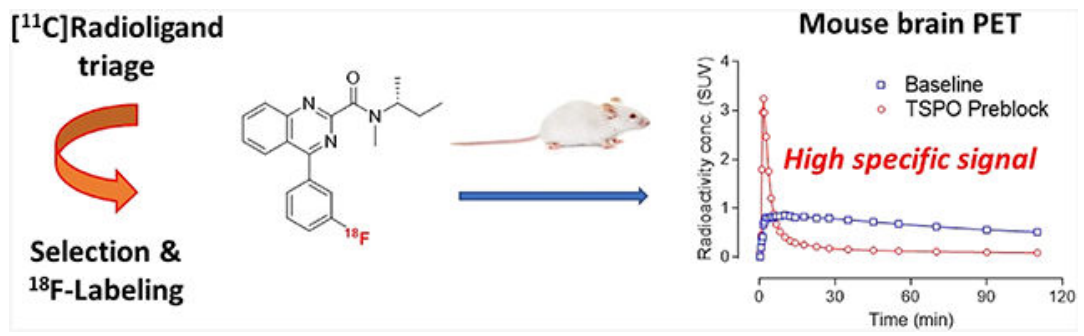

\section{INTRODUCTION}

There is growing evidence for the involvement of central inflammation in some major neuropsychiatric disorders, including depression ${ }^{1}$ and schizophrenia. ${ }^{2}$ Much of this evidence has been gained from positron emission tomography (PET) with selective radioligands to image translocator protein $18 \mathrm{kDa}$ (TSPO). ${ }^{1,2} \mathrm{TSPO}^{3}$ is expressed on the outer mitochondrial membrane in activated microglia, astrocytes, and macrophages ${ }^{4}$ and is implicated in several functions, including cholesterol transport ${ }^{5}$ and steroidogenesis. ${ }^{6}$ TSPO levels are very low in healthy human brains but are vastly upregulated in several human pathologies involving inflammation. ${ }^{1,2}$ Thus, TSPO is considered to be an important biomarker of neuroinflammation.

Several classes of radioligand have been developed for PET imaging of TSPO. ${ }^{7-9}$ The prototypical radioligand, $\left[{ }^{11} \mathrm{C}\right] \mathrm{PK} 11195$, first as racemate ${ }^{10}$ and later as $(R)$-enantiomer (Figure 1), ${ }^{11}$ has been in use for almost four decades to image TSPO in neurological and psychiatric disorders. However, this radioligand suffers from severe limitations, including low TSPO sensitivity and poor amenability to quantification. ${ }^{12,13}$ Therefore, considerable effort has been expended on the development of "second-generation" radioligands with improved properties. These radioligands include $\left[{ }^{11} \mathrm{C}\right] \mathrm{PBR} 28,{ }^{14-16}\left[{ }^{11} \mathrm{C}\right] \mathrm{DPA}-713,{ }^{17}$ $\left[{ }^{18} \mathrm{~F}\right]$ FBR,${ }^{18}$ and $\left[{ }^{18} \mathrm{~F}\right]$ FEPPA ${ }^{19}$ (Figure 1). Many of these second-generation radioligands show improved TSPO-specific signals but suffer from sensitivity to a single nucleotide polymorphism (SNP), namely, rs6971, ${ }^{20-22}$ which has an allelic frequency of about $30 \%$ in humans of European ancestry. This SNP is co-dominantly expressed, giving rise to three subject genotypes now called high-affinity binders (HABs), low-affinity binders (LABs), and mixed-affinity binders (MABs). ${ }^{20}$ The ratio of affinity for the two alleles can be considerable for many second-generation radioligands and notably reaches about 50 -fold for $\left[{ }^{11} \mathrm{C}\right]-\mathrm{PBR} 28 .{ }^{23,24}$ For this radioligand, brain uptake is negligible in LABs and they must be excluded from PET studies by prescreening of all subjects for TSPO genotype. ${ }^{25}$ PET data from MAB subjects must also be corrected for the lowering effect (50\%) of genotype on total specific binding. ${ }^{25}$

PK11195 shows low sensitivity to SNP rs6971 when tested in vitro. ${ }^{23}$ Therefore, this chemotype has been used as a template for the design of new radioligands that might provide higher TSPO imaging performance while showing low to negligible genotype sensitivity. Notably, a small structural modification to PK11195, namely, the conversion of its core isoquinolinyl ring into a quinazolinyl ring, has led to the discovery of a new high-affinity and less lipophilic TSPO ligand, $(R)-N$-(sec-butyl)-4-(2-chlorophenyl)- 
$N$-methylquina-zoline-2-carboxamide, ${ }^{26}$ now dubbed ER176, which retains low genotype sensitivity in vitro. ${ }^{27}$

ER176, when labeled with carbon-11 $\left(t_{1 / 2}=20.4 \mathrm{~min}\right)$, shows excellent brain kinetics and high TSPO-specific signal in PET studies of monkey ${ }^{27}$ and human brains. ${ }^{28,29}$ Moreover, and unlike most-second generation TSPO PET radioligands, $\left[{ }^{11} \mathrm{C}\right]$ ER176 (Figure 1) gives quantifiable PET imaging results in all three human subject genotypes. ${ }^{29}$ For these reasons, $\left[{ }^{11} \mathrm{C}\right] \mathrm{ER} 176$ is now regarded as one of the best performing radioligands for imaging and quantifying TSPO in human subjects. ${ }^{28}$ The production of this radioligand for this purpose has now been described in detail. ${ }^{30}$

Whereas $\left[{ }^{11} \mathrm{C}\right] \mathrm{ER} 176$ is an excellent PET radioligand, analogs that can be labeled with longer-lived fluorine-18 $\left(t_{1 / 2}=109.8 \mathrm{~min}\right)$ and provide comparable imaging performance could be more broadly useful, especially to the large number of imaging centers lacking access to short-lived carbon-11.

The initial aims of this study were (i) to replace the 2-chloro substituent of ER176 with either a ring fluoro or trifluoromethyl substituent, (ii) to assess the effect of such a replacement on binding affinity to TSPO, (iii) to radiolabel each new ligand with carbon-11 in the common $\mathrm{N}$-methyl position matching that in $\left[{ }^{11} \mathrm{C}\right]$ ER 176 by taking advantage of a ${ }^{11} \mathrm{C}$-labeling procedure already well established in our laboratory, ${ }^{30}$ and (iv) to compare the behaviors of the new PET ${ }^{11} \mathrm{C}$-labeled ligands in mice. This study with ${ }^{11} \mathrm{C}$-labeled ligands would serve as a speedy screen to identify which, if any, of the new ligands would merit labeling with fluorine-18 and further evaluation in higher species. Therefore, the final aims of this study were to label the most promising ligand with fluorine-18 and to confirm mouse brain imaging behavior matching that of the ${ }^{11} \mathrm{C}$-labeled version.

\section{RESULTS AND DISCUSSION}

\section{Ligand Design.}

We considered modifications to the structure of ER176 that might provide possibilities for eventual labeling with fluorine-18 $\left(t_{1 / 2}=109.8 \mathrm{~min}\right)$. Replacement of the 2-chloro substituent in PK11195 with a 2-fluoro substituent is not detrimental to binding affinity for TSPO. ${ }^{31}$ A 2-fluoro substituent is also well tolerated in 4-phenyl-quinazoline-2carboxamide TSPO ligands related to ER176. ${ }^{32}$ Moreover, such a change is calculated with the Pallas for Windows software to reduce the lipophilicity of ER176 $(\log D=4.12)$ to a value $(\operatorname{cog} D=3.55)$ that would be more desirable for a brain PET radioligand (preferred $\operatorname{cog} D \sim 2.2)^{33}$ without altering the acceptably moderate total polar surface area (tPSA $=45 \AA^{2}$ ). The pendant phenyl ring in ER176 is quite electron-rich and therefore is not activated for classical aromatic nucleophilic substitution of a good leaving group with $\left[{ }^{18}\right.$ F $]$ fluoride ion. ${ }^{34}$ Nonetheless, labeling might be feasible through modern methods of aryl ring radiofluorination based on, for example, the use of hypervalent iodine $\mathrm{e}^{35}$ or boronic acid ester precursors. ${ }^{36}$ Therefore, we aimed to explore the replacement of the chloro substituent in ER176 with a fluoro substituent as well as the effects of the fluoro substituent ring position. 
Several methods for labeling aryl trifluoromethyl groups with fluorine-18 have emerged, mostly based on the use of $\left[{ }^{18} \mathrm{~F}\right]$ trifluoromethyl-copper(I) derived from $\left[{ }^{18} \mathrm{~F}\right]$ fluoroform. 37-41 They are generally quite efficient, albeit with molar activity outcomes constrained to moderate levels. An aryl trifluoromethyl group is expected to be metabolically stable and only marginally increases lipophilicity over an aryl chloro substituent (by $\sim 0.17 \log D$ units) without increasing tPSA. Moreover, an aryl trifluoromethyl group can provide an alternative site for labeling with carbon-11 at high molar activity by the use of readily prepared $\left[{ }^{11} \mathrm{C}\right]$ fluoroform as its $\left[{ }^{11} \mathrm{C}\right]$ trifluoromethyl-copper(I) derivative. ${ }^{42-44}$ Therefore, we also aimed to prepare radioligands in which the 2-chloro substituent of the pendant phenyl ring in ER176 is replaced with a single trifluoromethyl group at the 2-, 3-, or 4position.

\section{Synthesis of Fluorine-Containing Ligands.}

ER176 and many close analogs have been prepared by multistep pathways from appropriately substituted 2 -aminobenzophenones. ${ }^{26}$ The benzophenones are treated with glyoxylic acid followed by an amidation (Scheme 1A). We devised a new synthetic route to have faster access to our target ER176 derivatives. This route involves the synthesis of a chiral quinazoline amide synthon for rapid coupling to commercially available fluorocontaining aryl boronic acids (Scheme 1B).

Several tautomerizable 2-quinoxalinones have been shown to couple directly with aryl boronic acids upon treatment with phosphonium salt activators, such as bromo-trispyrrolidinophosphonium hexafluorophosphate (PyBroP) ${ }^{45}$ We considered that this approach might be applied to a homochiral tautomerizable oxoquinazoline amide that might then be used as a common synthon for the preparation of a variety of fluorine-containing ER176 analogs. The new pathway would combine mild phosphonium salt activated coupling $\left(\mathrm{Et}_{3} \mathrm{~N}\right.$, 1,4-dioxane, RT) with classical Suzuki-Miyaura cross-coupling conditions $\left(\operatorname{Pd}\left(\mathrm{PPh}_{3}\right)_{4}\right.$, $\mathrm{Na}_{2} \mathrm{CO}_{3}$, water, heating) in a single pot (Scheme 2). The required homochiral synthon, ( $R$ )- $N$-(sec-butyl)- $N$-methyl-4-oxo-3,4-dihydroquinazoline-2-carboxamide (2), was obtained as follows. First, $(R)-N$-methylbutan-2-aminium chloride was prepared as previously reported $^{46}$ and stored under vacuum until ready for use. The ester, ethyl 4-oxo-3,4dihydroquinazoline-2-carboxylate (1), was then treated with the aminium salt in a Weinreb reaction ${ }^{47}$ in the presence of trimethylaluminum to give $\mathbf{2}$ in very high yield. The presence of a tertiary carboxamide in $\mathbf{2}$ leads to rotamers, with the dominant $E$ and $Z$ rotamer types clearly detected by solution ${ }^{1} \mathrm{H}$ and ${ }^{13} \mathrm{C}$ NMR. The ratio and significance of such rotamers in structurally similar TSPO ligands, such as PK11195, have been discussed thoroughly. ${ }^{48}$

Treatment of the synthon 2 with PyBroP followed by coupling in the same pot with variously selected fluorinated aryl boronic acids under palladium catalysis led to the target fluorine-containing compounds 3a-3f in overall yields between 35 and 50\%. Reaction yields were limited by the emergence of several byproducts, including some from homocoupling and protodeboronation of the aryl boronic acid. We therefore investigated the conditions for each step to improve yields. From ${ }^{31} \mathrm{P}$ NMR and ${ }^{19} \mathrm{~F}$ NMR, we found that the coupling of PyBroP with 2 in 1,4-dioxane was almost complete after $2 \mathrm{~h}$ of stirring at RT. Decreasing the amount of PyBroP to either 1.5 or 1.8 equiv instead of 2.4 equiv and extending the 
reaction time to $12 \mathrm{~h}$ greatly increased the yields. After the intermediate phosphonium salt had formed and precipitated, the aryl boronic acid, palladium catalyst, and sodium carbonate were added with water and heated to $100{ }^{\circ} \mathrm{C}$ until reaction was complete $(2-4 \mathrm{~h})$. A decrease of the ratio of oxoquinazoline to aryl boronic acid from 4 to 1.8 almost completely avoided byproducts to give reproducible yields of $\mathbf{3 a - 3 f}$ in the $66-81 \%$ range.

The new ligands were assayed in rat kidney and human U87MG cells for inhibition of $\left[{ }^{3} \mathrm{H}\right] \mathrm{PK} 11195$ binding to TSPO. Each ligand was found to have high affinity with a $K_{\mathrm{i}}$ value in the low nanomolar range (Table 1). These assays showed that substitution of the 2-chloro substituent in ER176 with either a 2-fluoro or 2-trifluoromethyl substituent was negligibly detrimental to the binding affinity for TSPO. The 3- and 4-isomers also exhibited high affinity to TSPO, with the 3-trifluoromethyl compound $3 \mathbf{e}$ having the highest affinity (rat $K_{\mathrm{i}}$ $=1.44 \mathrm{nM}$; human U87MG, $1.19 \mathrm{nM}$ ) (Table 1). Notably, for each substituent position, the trifluoromethyl compound showed a lower $K_{\mathrm{i}}$ value than the fluoro compound. Affinities for rat kidney TSPO and human U87MG TSPO were highly comparable across the whole set of ligands, consistent with the highly conserved TSPO sequence homology across mammalian species (Table 1).

Human genotype sensitivity in vitro would be an important consideration in any eventual selection of a TSPO radioligand for labeling with fluorine-18 and evaluation in human. Therefore, we tested each ligand in brain cells from human HAB and LAB genotypes. Each ligand exhibited low sensitivity to TSPO genotype in vitro with $\mathrm{HAB} / \mathrm{LAB}$ affinity ratios (as represented by LAB/HAB $K_{\mathrm{i}}$ ratios) between 0.8 and 5.46. Compound $\mathbf{3 f}$ showed the lowest in vitro sensitivity with an affinity ratio of 0.8 , which is close to values already reported $^{23,27}$ for PK11195 (0.8 and 0.9). In this study, we found a slightly lower value (0.68) for PK11195. The value for $\mathbf{3 f}$ is lower than that (1.28) reported ${ }^{27}$ for ER176. Other values were equal to or greater than 2.0. Thus, the set of six new ligands showed overall encouraging in vitro properties for development as PET radioligands.

\section{Synthesis of $\mathbf{N}$-Desmethyl Compounds as Precursors for ${ }^{11} \mathrm{C}$-Labeling.}

To allow a quick comparison of new radioligands with $\left[{ }^{11} \mathrm{C}\right] \mathrm{ER} 176$, we decided to label all six new ligands by a generic ${ }^{11} \mathrm{C}-\mathrm{N}$-methylation procedure, similar to that in place in our laboratory for $\left[{ }^{11} \mathrm{C}\right] \mathrm{ER} 176$ synthesis. The $\mathrm{N}$-desmethyl compounds $\mathbf{5 a - 5 f}$ that were required as precursors for labeling were prepared by the same route as the ligands, except that $(R)-2$ aminobutane was deployed to synthesize the desired desmethyl amide synthon 4 (Scheme 3). As expected, palladium-catalyzed coupling of $\mathbf{4}$ with the set of six fluorine-containing aryl boronic acids gave the corresponding precursors $\mathbf{5 a - 5 f}$ in good to high yields (65-89\%).

\section{${ }^{11}$ C-Radiochemistry.}

The desmethyl precursor $\mathbf{5 e}$ was selected as a substrate for optimizing radiolabeling conditions. After dissolution of $\mathbf{5 e}$ in DMSO at RT, treatment with powdered $\mathrm{KOH}$ (1.2 equiv) gave a yellow solution. Treatment of the precursor solution with $\left[{ }^{11} \mathrm{C}\right]$ iodomethane followed by heating at $85{ }^{\circ} \mathrm{C}$ for 2 min gave the targeted radioligand $\left[{ }^{11} \mathrm{C}\right] 3 \mathbf{e}$. However, we observed a wide variability in labeling yield that we attributed to the variation in ambient moisture levels during base preparation. 
A series of conditions, including solvents, bases, and reaction times, and also labeling platforms, were tested to optimize labeling yields. Bases in solutions, such as $t$-BuOK or TBAH in THF, were less reliable than the solid bases $\mathrm{NaH}, \mathrm{KOH}$, or $t$-BuOK, with the latter giving the best yield. The reaction did not proceed in DMF or THF and performed best in very dry DMSO. The radioligand was produced in higher yields from 5 min reaction times than from 2 min reaction times. Additionally, a synthesis using the "loop method" 50 failed to provide any labeled product. Overall, we found that reproducible and acceptably high yields were obtained when the precursor and solid $t$-BuOK (1.0 and 1.2 equiv, respectively) were loaded into an oven-dried vial within a glove-box under nitrogen followed by treatment with $\left[{ }^{11} \mathrm{C}\right]$ iodomethane in DMSO at $85^{\circ} \mathrm{C}$ for $5 \mathrm{~min}$. Under these conditions, precursors 5a-5f gave the corresponding radioligands $\left[{ }^{11} \mathrm{C}\right] 3 \mathbf{a}-\left[{ }^{11} \mathrm{C}\right] \mathbf{3 f}$ in moderate decay-corrected formulated yields $(8-15 \%)$ from cyclotron-produced $\left[{ }^{11} \mathrm{C}\right]$ carbon dioxide (Scheme 4).

TSPO radioligands $\left[{ }^{11} \mathrm{C}\right] \mathbf{3 a}-\left[{ }^{11} \mathrm{C}\right] \mathbf{3 f}$ were obtained in excellent radiochemical purities (>99\%) and with molar activities in the range of $229-351 \mathrm{GBq} / \mu \mathrm{mol}$. The formulated radioligands were free of appreciable chemical impurities. Radiosyntheses required 40-45 min for the trifluoromethyl radioligands and 52-55 min for the fluoro radioligands. Each radioligand was formulated for intravenous injection in saline $(0.9 \%, \mathrm{w} / \mathrm{v})$-ethanol $(9: 1 \mathrm{v} / \mathrm{v})$. Radioligand identity was verified by coinjection with the corresponding reference compound and by LC-MS analysis of the associated carrier. All the radioligands were greater than $97 \%$ radiochemically stable in the phosphate buffer for at least $2.5 \mathrm{~h}$. They were also stable for at least $60 \mathrm{~min}$ at $37^{\circ} \mathrm{C}$ in brain homogenate tissues from rats, monkeys, and humans $(\sim 100 \%)$.

$\log D$ values, as indices of lipophilicity, were obtained by measuring the distribution coefficient of each radioligand between the sodium phosphate buffer ( $\mathrm{pH} 7.4)$ and 1-octanol at RT. All six compounds exhibited $\log D$ values between 3.01 and 3.93, values that fall within the range that is considered compatible with good blood-brain barrier permeability $(1.5<\log D<4)$. High lipophilic efficiency (lipE), a $\log$ ratio of affinity $\left(\mathrm{p} K_{\mathrm{i}}\right)$ to lipophilicity $(\log D)$, is generally desirable in a PET radioligand for promoting a high ratio of specific to nonspecific signal. Four of the new radioligands $\left[{ }^{11} \mathrm{C}\right] \mathbf{3 a}-\left[{ }^{11} \mathrm{C}\right] \mathbf{3 d}$ have lipE values closer to the value of ER176 than to the lower and less desirable value of PK11195 (Table 1). $\left[{ }^{11} \mathrm{C}\right] 3 \mathbf{e}-\left[{ }^{11} \mathrm{C}\right] 3 \mathbf{3 f}$ also have higher lipE values than PK11195.

The plasma free fraction $\left(f_{\mathrm{P}}\right)$ of a PET radioligand is a key factor with respect to the delivery of a PET radioligand into the brain from blood. Only free radioligand is able to cross the blood-brain barrier. High radioligand $f_{\mathrm{P}}$ values are readily measurable with precision and accuracy and are therefore desirable for quantitative PET determination of target radioligand binding sites with compartmental modeling. With radioligands $\left[{ }^{11} \mathrm{C}\right] \mathbf{3 a}-$ $\left[{ }^{11} \mathrm{C}\right] 3 \mathbf{3 f}$ available, opportunity was taken to measure $f_{\mathrm{P}}$ in monkey and human plasma. Each of these radioligands showed high $f_{\mathrm{P}}$ values in both species (Supporting Information, Table $\mathrm{S} 1)$. Free fractions tended to decrease with increasing lipophilicity $(\log D)$ value.

In summary, radioligands $\left[{ }^{11} \mathrm{C}\right] 3 \mathbf{a}-\left[{ }^{11} \mathrm{C}\right] \mathbf{3 f}$ showed in vitro properties, such as high TSPO affinity, moderate lipophilicity, high lipE, and high $f_{\mathrm{P}}$, that warranted further evaluation of these radioligands with PET in vivo. 


\section{PET Imaging of ${ }^{11} \mathrm{C}$-Labeled Radioligands in the Mouse Brain.}

The TSPO protein homology is highly conserved across the mammalian species. Mouse TSPO is $96 \%$ homologous with rat TSPO. ${ }^{51}$ TSPO density has been reported as $34 \mathrm{nM}$ in mouse brain membranes ${ }^{52}$ and as $104 \mathrm{nM}$ in mouse cerebral cortex ${ }^{53}$ Moreover, we found that TSPO is over twice as abundant in the mouse brain $(1242 \mathrm{fmol} / \mathrm{mg}$ protein, equivalent to $124 \mathrm{nM}$ ) as in the rat brain ( $580 \mathrm{fmol} / \mathrm{mg}$ protein, equivalent to $58 \mathrm{nM}$ ) (Supporting Information, Figure S1 and Table S2). Because mouse brain TSPO is dense and has high structural homology with TSPO in other mammalian species and because we are able to image groups of six mice readily and simultaneously with PET in a single camera, mouse offered a convenient animal model for screening the new radioligands.

Figure 2 shows the mean time-activity curves for the whole mouse brain at baseline and after TSPO blockade with PK11195 (5 mg/kg, i.v.) for each of the six intravenously administered radioligands, $\left[{ }^{11} \mathrm{C}\right] \mathbf{3 a}-\left[{ }^{11} \mathrm{C}\right] \mathbf{3 f}$, and for $\left[{ }^{11} \mathrm{C}\right] \mathrm{ER} 176$ to allow direct comparison. The radioligands were administered at high molar activities with mean injected masses varying from 0.39 to $1.22 \mu \mathrm{g} / \mathrm{kg}$. We estimate that brain TSPO occupancy would vary between 0.8 and $2.5 \%$ for $\left[{ }^{11} \mathrm{C}\right] \mathbf{3 a}-\left[{ }^{11} \mathrm{C}\right] \mathbf{3 f}$ and would be $2.6 \%$ for $\left[{ }^{11} \mathrm{C}\right] \mathrm{ER} 176$ at baseline (Supporting Information, Table S3), and would therefore have had little impact on recorded whole brain radioactivity curves.

At baseline, all three mono-fluoro radioligands, $\left[{ }^{11} \mathrm{C}\right] \mathbf{3 a}-\left[{ }^{11} \mathrm{C}\right] \mathbf{3 c}$, gave a peak radioactivity uptake in the brain of about $0.8,0.85$, and $0.95 \mathrm{SUV}$ at $22.5,55$, and 14 min, respectively, which were each followed by a slow radioactivity decline for $\left[{ }^{11} \mathrm{C}\right] \mathbf{3 a}$ and $\left[{ }^{11} \mathrm{C}\right] \mathbf{3 b}$ and a somewhat faster decline for $\left[{ }^{11} \mathrm{C}\right] \mathbf{3 c}$. These three radioligands have very similar rat TSPO affinities and lipophilicities ( $\log D$ values) (Table 1$)$. Concerning the three trifluoromethyl radioligands, the meta trifluoromethyl radioligand $\left[{ }^{11} \mathrm{C}\right] \mathbf{3 e}$ showed similar brain radioactivity kinetics to the meta fluoro radioligand $\left[{ }^{11} \mathrm{C}\right] \mathbf{3 b}$, with a peak radioactivity uptake of $1.06 \mathrm{SUV}$ at $45 \mathrm{~min}$. The two other trifluoromethyl radioligands, $\left[{ }^{11} \mathrm{C}\right] \mathbf{3 d}$ and $\left[{ }^{11} \mathrm{C}\right] \mathbf{3 f}$, gave slightly lower peak radioactivity brain uptakes of 0.66 and $0.73 \mathrm{SUV}$ at 8 and $17.5 \mathrm{~min}$, respectively, each followed by slow radioactivity decline. Their brain radioactivity kinetics were therefore quite similar to those of the ortho and para fluoro radioligands $\left[{ }^{11} \mathrm{C}\right] \mathbf{3 a}$ and $\left[{ }^{11} \mathrm{C}\right] \mathbf{3 c}$, respectively. The baseline kinetics of brain radioactivity for $\left[{ }^{11} \mathrm{C}\right]$ ER 176 were broadly similar to those of the six new radioligands in terms of peak radioactivity uptake around 1.0 SUV and showed a subsequent slow decline like most of the new radioligands (Figure 2).

Preblocking of TSPO with PK11195 had strong effects on brain time-activity curves for all six radioligands that were broadly comparable to that seen for $\left[{ }^{11} \mathrm{C}\right] \mathrm{ER} 176$ (Figure 2). Relative to the baseline curves, these curves obtained under TSPO preblock conditions showed the same pattern, namely, an early fast radioactivity uptake into brain to a much higher peak followed by a subsequent rapid decline to a lower terminal level. This pattern is attributed to (1) the blockade of radioligand binding to TSPO in peripheral TSPO-rich organs (e.g., kidney, heart, and lung), causing a higher initial input of radioligand into the brain from an increased level of free radioligand in plasma, and (2) the presence of predominantly nonspecific binding at any time in the brain, unlike the baseline curve that 
has predominantly both specific and nonspecific binding. Some free radioligand will also be in the brain under all conditions. The ratio of the area under the curve in the baseline scan to that in the preblock scan at a late time interval that avoids early radioligand distribution may therefore be taken as a crude estimate of total to nonspecific binding. Percentage decreases from the areas under the curve at baseline to those under preblock condition over the late interval of 80 to $100 \mathrm{~min}$ were therefore used to compare radioligand performances (Figure 3). Blocking effects ranged from 71 to $88 \%$ for the three mono-fluoro radioligands $\left[{ }^{11} \mathrm{C}\right] \mathbf{3 a}-\left[{ }^{11} \mathrm{C}\right] \mathbf{3 c}$ and the meta-trifluoromethyl radioligand $\left[{ }^{11} \mathrm{C}\right] \mathbf{3 e}$. These values compared well with that of the established TSPO radioligand $\left[{ }^{11} \mathrm{C}\right] \mathrm{ER} 176$ (72\%). Blocking effects were much lower for $\left[{ }^{11} \mathrm{C}\right] \mathbf{3 d}(33 \%)$ and $\left[{ }^{11} \mathrm{C}\right] \mathbf{3 f}(48 \%)$. Terminal SUV values for these two radioligands in preblocked scans were higher than for the other radioligands.

Based on blocking effects from these mouse imaging results, $\left[{ }^{11} \mathrm{C}\right] \mathbf{3 b}$ appeared to be the marginally preferred radioligand (over $\left[{ }^{11} \mathrm{C}\right] \mathbf{3} \mathbf{c}$ and $\left[{ }^{11} \mathrm{C}\right] \mathbf{3 e}$ ). Moreover, we considered that $\mathbf{3 b}$ would be amenable to straightforward labeling direct from cyclotron-produced $\left[{ }^{18} \mathrm{~F}\right]$ fluoride on a suitable precursor in high molar activity and that this could be achieved in already available automated radiosynthesis apparatus that would be suitable for eventual production of $\left[{ }^{18} \mathrm{~F}\right] \mathbf{3} \mathbf{b}$ in a CGMP environment. The labeling of $\mathbf{3 e}$ with fluorine-18 would be possible from $\left[{ }^{18} \mathrm{~F}\right]$ fluoroform, but, by contrast, this approach would require considerable extra effort on optimizing molar activity and on achieving automated production. For all these reasons, we selected $\mathbf{3 b}$ for labeling with fluorine- 18 and for comparative evaluation as a radioligand with PET in mice.

\section{Synthesis of Precursor for Labeling 3b with Fluorine-18.}

Different methods were considered for labeling $3 b$ with no-carrier-added (NCA) cyclotronproduced $\left[{ }^{18} \mathrm{~F}\right]$ fluoride ion. These included methods based on a diaryliodonium salt or an iodonium ylide as precursor because such methods might be expected to allow the introduction of nucleophilic $\left[{ }^{18} \mathrm{~F}\right]$ fluorine into the electron-neutral ring of $\mathbf{3 b}$. A pilot investigation showed that an aryl(mesityl)iodonium triflate might be readily accessible as a precursor for copper-mediated radiofluorination. ${ }^{54}$ Thus, treatment of 2 with a 3-N-Bocamino-aryl boronic acid gave compound $\mathbf{6}$ in high yield with no other major byproducts (Scheme 5). Brief sonication of 6 in TFA/DCM gave the free amine 7, which was readily diazotized with sodium nitrite in the presence of potassium iodide to give the 3-iodo compound $\mathbf{8}$ in good yield. The desired aryl(mesityl)iodonium salt $\mathbf{9}$ was obtained from $\mathbf{8}$ by modifying a recently reported oxidation-purification procedure. ${ }^{55}$ Specifically, treatment of 8 with $m$-chloroperbenzoic acid ( $m C P B A$ ) and mesitylene in the presence of a large excess of triflic acid gave a di-cation salt that was then purified on a short column of basic alumina to provide $\mathbf{9}$ in good yield.

\section{${ }^{18} \mathrm{~F}$-Labeling of $3 b$.}

For the labeling of $\mathbf{3 b}$ with fluorine-18, the precursor 9 was dissolved in DMF and mixed with a solution of tetrakis(acetonitrile)-copper(I) triflate. The resulting solution was treated with a mixture of $\left[{ }^{18} \mathrm{~F}\right]$ fluoride ion and 4,7,13,16,21,24-hexaoxa-1,10diazabicyclo[8.8.8] hexacosane (K 2.2.2) $-\mathrm{K}_{2} \mathrm{CO}_{3}$ solution at $95{ }^{\circ} \mathrm{C}$. The radiochemical yield reached $26 \%$ within $20 \mathrm{~min}$. When a similar reaction mixture was heated by microwave 
irradiation for $3 \mathrm{~min}$, the yield nearly doubled to $51 \%$ (Scheme 6). We therefore used microwave irradiation to prepare $\left[{ }^{18} \mathrm{~F}\right] \mathbf{3 b}$ for imaging in mice. Overall, the formulated $\left[{ }^{18} \mathrm{~F}\right] \mathbf{3 b}$ was obtained in $21 \%$ yield $(n=3)$, with a radiochemical purity higher than $99 \%$.

\section{PET Imaging of $\left[{ }^{18} \mathrm{~F}\right] 3 \mathrm{~b}$ in the Mouse Brain.}

Radioligand $\left[{ }^{18} \mathrm{~F}\right] \mathbf{3 b}$ was evaluated with PET in mice in the same way as $\left[{ }^{11} \mathrm{C}\right] \mathbf{3 b}$. The mean time-activity curves for the whole brain in three mice at baseline and another three mice after TSPO blockade with PK11195 (5 mg/kg, i.v.) are shown in Figure 4A. At baseline, $\left[{ }^{18} \mathrm{~F}\right] \mathbf{3 b}$ gave a peak radioactivity uptake in the brain of about $0.8-0.9 \mathrm{SUV}$ at $17 \mathrm{~min}$ followed by a slow but gradual radioactivity decline. As observed with $\left[{ }^{11} \mathrm{C}\right] \mathbf{3 b}$, preblocking with PK11195 had a strong effect on brain time-activity curves. The blocking effect for $\left[{ }^{18} \mathrm{~F}\right] \mathbf{3 b}$ was $82 \%$ (Figure $4 \mathrm{~B}$ ), which compares well to the $88 \%$ observed with $\left[{ }^{11} \mathrm{C}\right] \mathbf{3 b}$. These data confirm that $\left[{ }^{18} \mathrm{~F}\right] \mathbf{3 b}$ behaves as expected and very similar to its ${ }^{11} \mathrm{C}$-labeled analogue, $\left[{ }^{11} \mathrm{C}\right] \mathbf{3 b}$.

Metabolism of small drug-like molecules is generally considered to occur faster in mice than in higher species and also by possibly different routes. In this study, we did not investigate the metabolism of any of the radioligands. Nor did we directly assess whether radiometabolites accumulated in the brain, either by entry from plasma or through formation in brain. Nonetheless, the similarity of brain time-activity curves at baseline and after TSPO preblock for $\mathbf{3 b}$ that has been labeled in different positions strongly suggests that activity in mouse brain is not contaminated with radiometabolites to any great extent. Evaluation of $\left[{ }^{18} \mathrm{~F}\right] \mathbf{3 b}$ in a higher species more relevant to human will need to assess its metabolism in more detail. $\left[{ }^{11} \mathrm{C}\right] \mathrm{ER} 176$ does not have problems from radiometabolites for quantifying TSPO in human. The PET data obtained here on $\left[{ }^{18} \mathrm{~F}\right] \mathbf{3 b}$, and their similarity with those from $\left[{ }^{11} \mathrm{C}\right] \mathrm{ER} 176$, augur well for advancing the further evaluation of $\left[{ }^{18} \mathrm{~F}\right] \mathbf{3 b}$ into higher species.

\section{CONCLUSIONS}

Mono-fluoro and trifluoromethyl analogs of ER176 were readily accessible from a new homochiral synthon $\mathbf{2}$. Similarly, the desmethyl precursors for radiolabeling were readily obtained from an analogous homochiral synthon 4. All six fluorine-containing ligands showed excellent properties in vitro for PET radioligand development and were amenable to labeling by a generic ${ }^{11} \mathrm{C}$-methylation protocol. PET imaging in mice showed that each ${ }^{11} \mathrm{C}$ labeled ligand entered the brain and provided a sizeable TSPO-specific signal. In this simple and rapid screen in mice, radioligands $\left[{ }^{11} \mathrm{C}\right] \mathbf{3 a}-\left[{ }^{11} \mathrm{C}\right] \mathbf{3} \mathbf{c}$ and $\left[{ }^{11} \mathrm{C}\right] \mathbf{3 e}$ showed TSPO imaging performance similar to or better than that of $\left[{ }^{11} \mathrm{C}\right] \mathrm{ER} 176 .\left[{ }^{11} \mathrm{C}\right] \mathbf{3 b}$, the 3 -fluoro analog of $\left[{ }^{11} \mathrm{C}\right]$ ER176, marginally displayed the most promising imaging behavior. Therefore, a method was devised for labeling $\mathbf{3 b}$ with fluorine- 18 based on treating a synthesized aryl(mesityl)iodonium salt with no-carrier-added cyclotron-produced $\left[{ }^{18} \mathrm{~F}\right]$ fluoride ion. $\left[{ }^{18} \mathrm{~F}\right] \mathbf{3 b}$ gave comparably promising imaging results in the mouse brain to those of $\left[{ }^{11} \mathrm{C}\right] \mathbf{3 b}$ and therefore warrants further evaluation in nonhuman primates. 


\section{EXPERIMENTAL SECTION}

\section{General Materials and Methods.}

$\left[{ }^{11} \mathrm{C}\right]$ ER 176 was produced for intravenous injection as described previously. ${ }^{27}(R)-N$ Methyl-2-butanamine hydrochloride was prepared freshly from $(R)-(-)-2$-aminobutane as reported ${ }^{46}$ and obtained as colorless needles: $\mathrm{mp}=118-119^{\circ} \mathrm{C},[a]_{\mathrm{D}}=+6.1^{\circ}(c=$ 5.2, EtOH $)\left(\mathrm{Lit}^{46}{ }^{46} \mathrm{~m} \cdot \mathrm{p}=120^{\circ} \mathrm{C} ;[a]_{\mathrm{D}}=+6.2^{\circ}(5.2, \mathrm{EtOH})\right.$. This reagent was stored under argon until ready for use. All other reagents were purchased from MilliporeSigma (Burlington, MA). Water from a purification apparatus (Milli-Q; Waters Corp., Columbia, MD) was used in all syntheses and radiosyntheses. DMSO on molecular sieves was obtained from Acros Organics BVBA (Geel, Belgium), and stored and used in a glove-box under nitrogen. All other solvents were purchased with the highest purity available from Alfa Aesar (Tewkesbury, MA) and used as purchased. All reactions requiring inert atmosphere were performed under argon. Thin layer chromatography (TLC) was performed on silica gel layers (type 60 F254; 400-630 mesh) with compounds visualized under UV light ( $\lambda=$ $254 \mathrm{~nm}$ ). Column chromatography was performed on silica gel with hexane/DCM-EtOAc mixtures as eluents. Flash chromatography was performed on a semi-automated apparatus (CombiFlash Rf + UV; Teledyne ISCO Inc., Lincoln, NE). The purities of new compound were $>95 \%$ as determined with high-performance liquid chromatography (HPLC) on a Luna C18 column ( $5 \mu \mathrm{m}, 250 \mathrm{~mm} \times 4.6 \mathrm{~mm}$; Phenomenex Torrance, CA) eluted isocratically with aq. $\mathrm{NH}_{4} \mathrm{OH}(10 \mathrm{mM})-\mathrm{MeCN}$ and with eluate monitored for absorbance at $254 \mathrm{~nm}$. Yields are recorded for chromatographically pure materials $(>98 \%)$.

Melting points were measured on a digital melting point apparatus (Stuart SMP 20). Optical rotations were measured at RT using the wavelength of the sodium D line at $589.3 \mathrm{~nm}$ on a Model P-1010 polarimeter (Jasco, Easton, MD).

${ }^{1} \mathrm{H}(400 \mathrm{MHz}),{ }^{13} \mathrm{C}(100 \mathrm{MHz})$, and ${ }^{19} \mathrm{~F}$ NMR (376.49 MHz) spectra were recorded in $\mathrm{CDCl}_{3}$ at RT on an Avance-400 spectrometer (Bruker, Billerica, MA) using the chemical shift of residual deuterated solvent as the internal standard. ${ }^{1} \mathrm{H}$ and ${ }^{13} \mathrm{C}$ chemical shifts are reported in $\delta$ units (ppm) downfield relative to the chemical shift for tetramethylsilane ( $\delta$ $=0$ ) and ${ }^{19} \mathrm{~F}$ chemical shifts relative to that for $\mathrm{CFCl}_{3}$. Abbreviations br, d, dd, m, q, quin, $\mathrm{s}$, st, and t denote broad, doublet, double of doublets, multiplet, quartet, quintuplet, singlet, sextuplet, and triplet, respectively. NMR spectra are shown in the Supporting Information.

Note that NMR spectra for tertiary amides show the presence of two amide bond rotamers in equilibrium, as previously observed in related compounds. ${ }^{32}$

$\gamma$-Radioactivity from carbon-11 and fluorine-18 was measured with a calibrated dose calibrator (Atomlab 300; Biodex Medical Systems, USA) or for low levels ( $<40 \mathrm{kBq}$ ) with a well-type $\gamma$-counter (model 1080 Wizard; Perkin Elmer, Boston, MA) having an electronic window set between 360 and $1800 \mathrm{keV}$. All radioactivity measurements were corrected for background and physical decay.

All radiochemistry was performed in lead-shielded hot-cells to ensure radiation protection to personnel. The main apparatus for radiochemistry consisted of a PETtrace MeI Process Module (GE Medical Systems, Severna Park, MD) for $\left[{ }^{11} \mathrm{C}\right]$ iodomethane production and 
a semi-robotic Synthia instrument ${ }^{56}$ (Synthia AB, Uppsala, Sweden) upgraded ${ }^{57}$ with PLCcontrol for labeling reactions. Dedicated recipes were created in the Autorad software and followed step by step for each radiosynthesis. The HPLC apparatus for radioactive compound separation comprised a pump (P4.1S; Knauer, Berlin, Germany), a UV absorbance detector (UVD2.1S; Knauer), and a radioactivity detector (flow-count; Eckert \& Ziegler, Berlin, Germany). The Clarity Chromatography Station software (DataApex, Prague, Czech Republic) was used to record the chromatograms. Equipment for radio-HPLC analyses comprised a pump (DGU-20A3R; Shimadzu, Columbia, MD), a UV absorbance detector (CBM-20A; Shimadzu), and a radioactivity detector (flow-count; Eckert \& Ziegler).

All animals used in this study were handled in accordance with the Guide for the Care and Use of Laboratory Animals ${ }^{58}$ and the requirements of the National Institute of Mental Health Animal Care and Use Committee.

Results of statistical analyses are presented as mean \pm SD for $n \geq 3$.

\section{Chemistry.}

General Method 1: Synthesis of Amides by Weinreb Amidation.-A solution of $\operatorname{AlMe}_{3}(2.0 \mathrm{M}, 6.0 \mathrm{~mL}, 12.0 \mathrm{mmol})$ in hexanes was added dropwise to a solution of amine or ammonium salt (12.0 mmol) in dry 1,2-dichloroethane (DCE; $20 \mathrm{~mL})$. The mixture was stirred for $30 \mathrm{~min}$ at RT. Then a suspension of ethyl 4-oxo-3,4-dihydro-2quinazolinecarboxylate $\mathbf{1}(1.1 \mathrm{~g}, 5 \mathrm{mmol})$ in DCE $(10 \mathrm{~mL})$ was added in one portion. The mixture was refluxed for $2 \mathrm{~h}$, cooled to $0{ }^{\circ} \mathrm{C}$, quenched by slow addition of $2 \mathrm{M} \mathrm{HCl} \mathrm{(10}$ $\mathrm{mL}$ ) followed by water $(50 \mathrm{~mL})$, and shaken in a separatory funnel. The organic layer was collected, and the resulting solution was extracted with dichloromethane (DCM; $50 \mathrm{~mL} \times 2$ ). The organic phases were combined and then washed with water $(50 \mathrm{~mL})$, dried over $\mathrm{MgSO}_{4}$, and evaporated to dryness. The crude product was purified with chromatography on silica gel eluted with hexane/DCM/AcOEt/NEt 3 (35:25:40:0.01 by vol).

${ }^{1} \mathrm{H}$ NMR in $\mathrm{CDCl}_{3}$ revealed that each tertiary amide exists with at least two rotamers in a ratio of about 2:1 mainly due to amide bond rotation. Notably, the tertiary amide $\mathbf{3 d}$ showed four rotamers in the solution, whereas its $N$-desmethyl analogue $\mathbf{5 d}$ showed only two rotamers in ${ }^{13} \mathrm{C}$ NMR. For rotamers, chemical shifts in the ${ }^{1} \mathrm{H},{ }^{13} \mathrm{C}$, and ${ }^{19} \mathrm{~F}$ NMR data are reported first for the major rotamer $(\mathrm{M})$ and then the minor rotamer $(\mathrm{m})$, separated by an ampersand (\&). Coupling constants $J_{M}$ and $\mathrm{J}_{\mathrm{m}}$ are specified for each rotamer when distinct values are observed. When more than two rotamers are observed, peaks are reported in decreasing order of intensity.

(R)-N-sec-Butyl-N-methyl-4-oxo-3,4-dihydroquinazoline-2-carboxamide (2).General method 1 was used with $(R)$ - $N$-methylbutan-2-aminium chloride $(1.48 \mathrm{~g} ; 12.0$ mmol) to give 2 as a white powder $(1.15 \mathrm{~g}$, yield $88 \%)$. $[a]_{\mathrm{D}}=-118\left(c=0.25, \mathrm{CHCl}_{3}\right) . \mathrm{Mp}$ 84-86 ${ }^{\circ} \mathrm{C} .{ }^{1} \mathrm{H}$ NMR: $\delta 0.91 \& 0.94\left(\mathrm{t}, 3 \mathrm{H}, J_{M}=7.36 \mathrm{~Hz}, J_{m}=7.40 \mathrm{~Hz}\right), 1.33 \& 1.23(\mathrm{~d}, 3 \mathrm{H}$, $\left.J_{M}=6.60 \mathrm{~Hz}, J_{m}=6.76 \mathrm{~Hz}\right), 1.56-1.68(\mathrm{~m}, 2 \mathrm{H}), 2.89 \& 3.40(\mathrm{~s}, 3 \mathrm{H}), 5.25 \& 4.75(\mathrm{st}, 1 \mathrm{H}$, $\left.J_{M}=6.44 \mathrm{~Hz}, J_{m}=6.72 \mathrm{~Hz}\right), 7.57(\mathrm{t}, 1 \mathrm{H}, J=6.44 \mathrm{~Hz}), 7.79(\mathrm{~m}, 2 \mathrm{H}), 8.35(\mathrm{~d}, 1 \mathrm{H} J=8.24$ $\mathrm{Hz}), 10.26$ (br s, 1H). ${ }^{13} \mathrm{C}$ NMR: $\delta 11.03 \& 10.94,18.61 \& 17.23,26.40 \& 27.85,27.48 \&$ $30.74,55.18 \& 52.72,122.69 \& 122.65,126.72,128.35 \& 128.39,128.54 \& 128.52,134.62$ 
\& 134.64, $145.61 \& 145.67,147.45 \& 147.51,161.09 \& 160.94,161.28 \& 161.71$. HRMS: calcd for $\mathrm{C}_{14} \mathrm{H}_{18} \mathrm{~N}_{3} \mathrm{O}_{2} 260.1399[M+\mathrm{H}]^{+}$, found 260.1398 .

(R)-N-sec-Butyl-4-oxo-3,4-dihydroquinazoline-2-carboxamide (4).-General method 1 was used with $(R)$-2-aminobutane $(0.5 \mathrm{~g} ; 6.83 \mathrm{mmol})$ to give 4 as a white powder $(1.08 \mathrm{~g}$, yield $88 \%)$. $[a]_{\mathrm{D}}=-96^{\circ}\left(c=0.25, \mathrm{CHCl}_{3}\right) . \mathrm{Mp} 129-131{ }^{\circ} \mathrm{C} .{ }^{1} \mathrm{H}$ NMR: $\delta 0.88(\mathrm{t}$, $3 \mathrm{H}, J=12.0 \mathrm{~Hz}$ ), 1.23 (d, $3 \mathrm{H}, J=8.1 \mathrm{~Hz}$ ), 1.58 (quin, $2 \mathrm{H}, J=7.80 \mathrm{~Hz}$ ), 4.01 (st, $1 \mathrm{H}, J$ $=4.52 \mathrm{~Hz}) ; 7.50(\mathrm{~m}, 1 \mathrm{H}), 7.54(\mathrm{br} \mathrm{s}, 1 \mathrm{H}), 7.71(\mathrm{~m}, 2 \mathrm{H}), 8.28(\mathrm{~d}, 1 \mathrm{H}, J=7.81 \mathrm{~Hz}) .{ }^{13} \mathrm{C}$ NMR: $\delta 10.44,20.28,29.58,47.77,122.95,127.03,128.03,128.41,134.83,143.84,147.38$, 158.40, 160.69. HRMS: calcd for $\mathrm{C}_{13} \mathrm{H}_{16} \mathrm{~N}_{3} \mathrm{O}_{2}[M+\mathrm{H}]^{+}, 246.1243$; found, 246.1243 .

General Methods for the Pd-Catalyzed Direct Arylation with PyBroP.-General method 2a below was used to prepare compounds $\mathbf{3 a}-\mathbf{3 f}$ on $0.5 \mathrm{mmol}$ scale, and general method $2 \mathrm{~b}$ below was used to prepare compounds $\mathbf{5 a}-\mathbf{5 f}$ on $1.0 \mathrm{mmol}$ scale.

General Method 2a.-A mixture of the quinazoline amide ( $0.13 \mathrm{~g}, 0.5 \mathrm{mmol})$, PyBroP $(0.49 \mathrm{~g}, 1.05 \mathrm{mmol})$, and $\mathrm{Et}_{3} \mathrm{~N}(0.21 \mathrm{~mL}, 1.5 \mathrm{mmol})$ in 1,4-dioxane $(4 \mathrm{~mL})$ was stirred in a sealed tube at RT for $12 \mathrm{~h}$. Then, aryl boronic acid $(0.9 \mathrm{mmol}), \mathrm{Na}_{2} \mathrm{CO}_{3}(0.26 \mathrm{~g}, 2.5 \mathrm{mmol})$, $\mathrm{Pd}\left(\mathrm{PPh}_{3}\right)_{2} \mathrm{Cl}_{2}(17.5 \mathrm{mg}, 5 \mathrm{~mol} \%)$, and water $(0.5 \mathrm{~mL})$ were added, and the mixture was stirred at $100{ }^{\circ} \mathrm{C}$ for $4 \mathrm{~h}$. The mixture was cooled to RT, diluted with EtOAc, washed with water and then with brine, and dried over $\mathrm{MgSO}_{4}$. The organic phase was evaporated under vacuum to give an oily residue. Chromatography of the residue on silica gel (hexane/EtOAc; $60: 40, \mathrm{v} / \mathrm{v}$ ) gave the desired compound.

General Method 2b.-Method 2b was similar to method 2a except that all scales were doubled to use the quinazoline desmethyl amide $(0.245 \mathrm{~g}, 1.0 \mathrm{mmol})$.

(R)-(N-sec-Butyl)-4-(2-fluorophenyl)-N-methylquinazoline-2-carboxamide (3a). -General method 2a was used with 2-fluorophenyl boronic acid $(0.125 \mathrm{~g}, 0.9 \mathrm{mmol})$ to give 3a as an off-white powder $(0.13 \mathrm{~g}$, yield $75 \%)$. Mp: $116-118{ }^{\circ} \mathrm{C} .{ }^{1} \mathrm{H} \mathrm{NMR}\left(\mathrm{CDCl}_{3}\right)$ : $\delta 0.88 \& 1.04(\mathrm{t}, 3 \mathrm{H}, J=7.40 \mathrm{~Hz}), 1.23 \& 1.26\left(\mathrm{~d}, 3 \mathrm{H}, J_{M}=6.56 \mathrm{~Hz}, J_{m}=6.84 \mathrm{~Hz}\right)$, $1.41-1.73(\mathrm{~m}, 2 \mathrm{H}), 2.81 \& 3.04(\mathrm{~s}, 3 \mathrm{H}), 3.56 \& 4.85(\mathrm{st}, 1 \mathrm{H}, J=6.84 \mathrm{~Hz}), 7.70(\mathrm{~m}, 2 \mathrm{H})$, $7.85(\mathrm{~d}, 1 \mathrm{H}, J=6.76 \mathrm{~Hz}), 7.98(\mathrm{~m}, 2 \mathrm{H}), 8.01(\mathrm{~m}, 2 \mathrm{H}), 8.18(\mathrm{~m}, 1 \mathrm{H}) .{ }^{13} \mathrm{C}$ NMR: $\delta 11.05$ $\& 11.02,18.40 \& 17.20,25.75 \& 29.74,27.24 \& 26.63,55.76 \& 50.03,116.19 \& 115.98$, $116.25 \& 116.03(\mathrm{~d}, J=22.0 \mathrm{~Hz}), 123.08,124.60 \& 124.03$ and $124.71 \& 124.80(\mathrm{~d}, J=7.50$ $\mathrm{Hz}), 126.92,128.39,129.12 \& 129.09,131.93 \& 131.77,131.90(\mathrm{~d}, J=22.00 \mathrm{~Hz}), 132.06$, $134.44,150.62 \& 150.56,158.82,159.86(\mathrm{~d}, J=250.0 \mathrm{~Hz}), 165.12,167.65 \& 167.36 .{ }^{19} \mathrm{~F}$ NMR: $\delta-113.33 \&$ 113.07. HRMS calcd for $\mathrm{C}_{20} \mathrm{H}_{21} \mathrm{FN}_{3} \mathrm{O}[M+\mathrm{H}]^{+}, 338.1667$; found, 338.1669 .

(R)-(N-sec-Butyl)-4-(3-fluorophenyl)-N-methylquinazoline-2-carboxamide (3b). -General method 2a was used with 3-fluorophenyl boronic acid $(0.125 \mathrm{~g}, 0.9 \mathrm{mmol})$ to give $3 \mathbf{b}$ as an off-white powder $(0.11 \mathrm{~g}$, yield $66 \%)$. Mp: 97-99 ${ }^{\circ} \mathrm{C} .{ }^{1} \mathrm{H} \mathrm{NMR}\left(\mathrm{CDCl}_{3}\right)$ : $\delta 0.87 \& 1.04(\mathrm{t}, 3 \mathrm{H}, J=7.40 \mathrm{~Hz}), 1.24 \& 1.26\left(\mathrm{~d}, 3 \mathrm{H}, J_{M}=6.60 \mathrm{~Hz}, J_{m}=6.84 \mathrm{~Hz}\right)$, $1.40-1.72(\mathrm{~m}, 2 \mathrm{H}), 3.03 \& 2.82(\mathrm{~s}, 3 \mathrm{H}), 3.54 \& 4.85\left(\mathrm{st}, 1 \mathrm{H}, J_{M}=6.40 \mathrm{~Hz}, J_{m}=6.96 \mathrm{~Hz}\right)$, 7.28, (m, 1H), $7.54(\mathrm{~m}, 3 \mathrm{H}), 7.67(\mathrm{t}, 1 \mathrm{H}, J=8.16 \mathrm{~Hz}), 7.96(\mathrm{t}, 1 \mathrm{H}, J=8.08 \mathrm{~Hz}), 8.15(\mathrm{~m}$, 
2H). ${ }^{13} \mathrm{C}$ NMR: $\delta 11.07 \& 11.03,18.46 \& 17.21,26.64 \& 25.74,27.23 \& 29.76,50.02 \& 5$ $5.74,117.10 \& 117.26(\mathrm{~d}, J=25.15 \mathrm{~Hz}), 118.5(\mathrm{~d}, J=25.1 \mathrm{~Hz}), 122.07,125.94(\mathrm{~d}, J=7.04$ $\mathrm{Hz}), 126.00,126.67,128.48,129.40 \& 129.36,130.28 \& 130.21,134.29,138.86 \& 138.78$, $151.21,158.71,162.71(\mathrm{~d}, J=247.50 \mathrm{~Hz}), 167.39 \& 167.52,167.65 .{ }^{19} \mathrm{~F}$ NMR: $\delta-112.07$ $\&-112.06$. HRMS calcd for $\mathrm{C}_{20} \mathrm{H}_{21} \mathrm{FN}_{3} \mathrm{O}[M+\mathrm{H}]^{+}, 338.1669$; found, 338.1665.

(R)-(N-sec-Butyl)-4-(4-fluorophenyl)-N-methylquinazoline-2-carboxamide (3c). -General method 2a was used with 4-fluorophenyl boronic acid $(0.125 \mathrm{~g}, 0.9 \mathrm{mmol})$ to give $3 \mathbf{c}$ as a white powder $(0.14 \mathrm{~g}$, yield $81 \%)$. Mp: $133-135^{\circ} \mathrm{C} .{ }^{1} \mathrm{H} \mathrm{NMR}\left(\mathrm{CDCl}_{3}\right): \delta 0.87$ $\& 1.04(\mathrm{t}, 3 \mathrm{H}, J=7.40 \mathrm{~Hz}), 1.24 \& 1.27\left(\mathrm{~d}, 3 \mathrm{H}, J_{M}=6.80 \mathrm{~Hz}, J_{m}=6.84 \mathrm{~Hz}\right), 1.44-1.68$ $(\mathrm{m}, 2 \mathrm{H}), 3.03 \& 2.82(\mathrm{~s}, 3 \mathrm{H}), 3.56 \& 4.85\left(\mathrm{st}, 1 \mathrm{H}, J_{M}=6.32 \mathrm{~Hz}, J_{m}=6.80 \mathrm{~Hz}\right), 7.26(\mathrm{t}, 2 \mathrm{H}$, $J=8.64 \mathrm{~Hz}), 7.66(\mathrm{t}, 1 \mathrm{H}, J=7.24 \mathrm{~Hz}), 7.83(\mathrm{~m}, 2 \mathrm{H}), 7.95(\mathrm{t}, 1 \mathrm{H}, J=8.32 \mathrm{~Hz}), 8.14(\mathrm{~m}$, $2 \mathrm{H}) .{ }^{13} \mathrm{C}$ NMR: $\delta 11.06 \& 11.02,18.46 \& 17.20,25.72 \& 26.63,27.21 \& 29.75,55.71 \&$ $49.99,115.78(\mathrm{~d}, J=22.13 \mathrm{~Hz}), 122.15,126.77,128.35 \& 128.36,129.30 \& 129.34,132.26$ (d, $J=8.04 \mathrm{~Hz}$ ), 132.28, $132.90 \& 132.87,134.16,151.18 \& 151.15,158.68,164.12$ (dd, $J=$ $251.53 \mathrm{~Hz}), 167.49 \& 167.90,167.76 \& 167.81 .{ }^{19} \mathrm{~F}$ NMR: $\delta-110.04$ and -110.05 . HRMS calcd for $\mathrm{C}_{20} \mathrm{H}_{21} \mathrm{FN}_{3} \mathrm{O}[M+\mathrm{H}]^{+}$, 338.1667; found, 338.1666.

(R)-N-(sec-Butyl)-N-methyl-4-(2-(trifluoromethyl)phenyl)-quinazoline-2carboxamide (3d).-General method 2a was used with 2-(trifluoromethyl)phenyl boronic acid $(0.171 \mathrm{~g}, 0.9 \mathrm{mmol})$ to give $\mathbf{3 d}$ as a white powder $(0.14 \mathrm{~g}$, yield $75 \%)$. Mp: 122 $124{ }^{\circ} \mathrm{C} .{ }^{1} \mathrm{H} \mathrm{NMR}\left(\mathrm{CDCl}_{3}\right): \delta 0.85 \& 0.80$ and $0.98 \& 1.03(\mathrm{t}, 3 \mathrm{H}, J=7.40 \mathrm{~Hz}), 1.25 \& 1.18$ and $1.25(\mathrm{~d}, 3 \mathrm{H}, J=6.60 \mathrm{~Hz}), 1.40-1.65(\mathrm{~m}, 2 \mathrm{H}), 3.01 \& 3.00$ and $2.75 \& 2.74(\mathrm{~s}, 3 \mathrm{H}), 3.48$ \& $4.82(\mathrm{~m}, 1 \mathrm{H}), 7.45(\mathrm{~m}, 1 \mathrm{H}), 7.57(\mathrm{~m}, 2 \mathrm{H}), 7.71(\mathrm{~m}, 2 \mathrm{H}), 7.88(\mathrm{~m}, 1 \mathrm{H}), 7.95(\mathrm{~m}, 1 \mathrm{H}), 8.16$ $(\mathrm{m}, 1 \mathrm{H}) .{ }^{13} \mathrm{C}$ NMR: $\delta 11.02 \& 10.59,18.19 \& 17.14,27.28 \& 27.14$ and $25.68 \& 25.77$, 26.59 and $30.04 \& 29.36,55.72 \& 56.66$ and 49.95, $122.42,123.75$ (qd, $J=271 \mathrm{~Hz}), 126.70$ (m), 128.34, 128.70 and 128.66, 129.05, 129.61, 130.73 (qd, $J=24.15 \mathrm{~Hz}), 131.66,134.60$, 135.00, 150.55, $158.49 \& 158.32,167.51 \& 167.45,168.11 .{ }^{19} \mathrm{~F}$ NMR: $\delta-57.72,-57.75$, -57.86, -57.67. HRMS: calcd for $\mathrm{C}_{21} \mathrm{H}_{21} \mathrm{~F}_{3} \mathrm{~N}_{3} \mathrm{O}[M+\mathrm{H}]^{+}$388.1637; found, 388.1643.

(R)-N-(sec-Butyl)-N-methyl-4-(3-(trifluoromethyl)phenyl)-quinazoline-2carboxamide (3e).-General method 2a was used with 3-(trifluoromethyl)phenyl boronic acid $(0.171 \mathrm{~g}, 0.9 \mathrm{mmol})$ to give $3 \mathrm{e}$ as an off-white powder $(0.138 \mathrm{~g}$, yield $5 \%)$. Mp: $110-111{ }^{\circ} \mathrm{C} .{ }^{1} \mathrm{H}$ NMR $\left(\mathrm{CDCl}_{3}\right): \delta 0.87 \& 1.04(\mathrm{t}, 3 \mathrm{H}, J=7.40 \mathrm{~Hz}), 1.25 \& 1,27\left(\mathrm{~d}, 3 \mathrm{H}, J_{M}\right.$ $\left.=6.60 \mathrm{~Hz}, J_{m}=6.80 \mathrm{~Hz}\right), 1.42-1.73(\mathrm{~m}, 2 \mathrm{H}), 3.04 \& 2.82(\mathrm{~s}, 3 \mathrm{H}), 3.57 \& 4.85\left(\mathrm{st}, 1 \mathrm{H}, J_{M}=\right.$ $\left.6.36 \mathrm{~Hz}, J_{m}=6.76 \mathrm{~Hz}\right), 7.69(\mathrm{~m}, 2 \mathrm{H}), 7.85(\mathrm{~d}, 1 \mathrm{H}, J=7.36 \mathrm{~Hz}), 7.98(\mathrm{~m}, 2 \mathrm{H}), 8.06(\mathrm{~m}, 2 \mathrm{H})$, $8.19(\mathrm{~m}, 1 \mathrm{H}) .{ }^{13} \mathrm{C}$ NMR: $\delta 11.02 \& 11.04,18.46 \& 17.22,25.77 \& 27.22,26.63 \& 29.79$, $55.79 \& 50.05,122.04 \& 122.07,123.80(\mathrm{qd}, J=274.6 \mathrm{~Hz}), 125.19,126.38 \& 126.35$, $126.97(\mathrm{~m}), 128.75,129.22 \& 129.20,129.46 \& 129.52,131.24(\mathrm{q}, J=31.10 \mathrm{~Hz}), 133.41$ $\& 133.51,134.44,137.52,151.25 \& 151.17,158.71,167.33 \& 167.51,167.59 .{ }^{19}$ F NMR: $\delta-62.68 \&-62.61$. HRMS: calcd for $\mathrm{C}_{21} \mathrm{H}_{21} \mathrm{~F}_{3} \mathrm{~N}_{3} \mathrm{O}[M+\mathrm{H}]^{+}$, 388.1637; found, 388.1637.

(R)-N-(sec-Butyl)-N-methyl-4-(4-(trifluoromethyl)phenyl)-quinazoline-2carboxamide (3f).-General method 2a was used with 4-(trifluoromethyl)phenyl boronic acid (0.171 g, $0.9 \mathrm{mmol})$ to give $\mathbf{3 f}$ as a white powder $(0.127 \mathrm{~g}$, yield 69\%). Mp: 
135-136 ${ }^{\circ} \mathrm{C} .{ }^{1} \mathrm{H}$ NMR $\left(\mathrm{CDCl}_{3}\right): \delta 0.87 \& 1.04(\mathrm{t}, 3 \mathrm{H}, J=7.36 \mathrm{~Hz}), 1.25 \& 1.27\left(\mathrm{~d}, 3 \mathrm{H}, J_{M}\right.$ $\left.=6.56 \mathrm{~Hz}, J_{m}=6.84 \mathrm{~Hz}\right), 1.68-1.72(\mathrm{~m}, 2 \mathrm{H}), 3.03 \& 2.83(\mathrm{~s}, 3 \mathrm{H}), 3.56 \& 4.85\left(\mathrm{st}, 1 \mathrm{H}, J_{M}\right.$ $\left.=6.36 \mathrm{~Hz}, \mathrm{~J}_{\mathrm{m}}=8.12 \mathrm{~Hz}\right), 7.68(\mathrm{t}, 1 \mathrm{H}, J=7.61 \mathrm{~Hz}), 7.84(\mathrm{~d}, 2 \mathrm{H}, J=7.60 \mathrm{~Hz}), 7.92(\mathrm{~m}, 2 \mathrm{H})$, $7.96(\mathrm{~m}, 1 \mathrm{H}), 8.08(\mathrm{~m}, 1 \mathrm{H}), 8.20(\mathrm{t}, 1 \mathrm{H}, J=7.38 \mathrm{~Hz}) .{ }^{13} \mathrm{C}$ NMR: $\delta 11.08 \& 11.02,18.48$ $\& 17.23,25.75 \& 29.78,27.22 \& 26.63,55.78 \& 50.07,122.09,123.89$ (qd, $J=272.66 \mathrm{~Hz}$ ), $125.58(\mathrm{qd}, J=4.62 \mathrm{~Hz}), 126.46,128.66,129.49,129.66,130.52 \& 130.60,132.13(\mathrm{q}, J=$ $32.19 \mathrm{~Hz}), 134.44,140.20,151.20 \& 152.17,158.73,167.53 \& 167.34,167.61 .{ }^{19} \mathrm{~F}$ N NMR: $\delta-62.79 \&-62.80$. HRMS: calcd for $\mathrm{C}_{21} \mathrm{H}_{21} \mathrm{~F}_{3} \mathrm{~N}_{3} \mathrm{O}[M+\mathrm{H}]^{+}$, 388.1637; found, 388.1644.

(R)-N-(sec-Butyl)-4-(2-fluorophenyl)quinazoline-2-carboxamide (5a).-General method $2 \mathrm{~b}$ was used with 2-fluorophenyl boronic acid $(0.251 \mathrm{~g}, 1.8 \mathrm{mmol})$ to give $\mathbf{5 a}$ as a white powder $(0.249 \mathrm{~g}$, yield $7 \%)$. Mp: $94-96{ }^{\circ} \mathrm{C} .{ }^{1} \mathrm{H} \mathrm{NMR}\left(\mathrm{CDCl}_{3}\right): \delta 0.92(\mathrm{t}, 3 \mathrm{H}, J=$ $7.15 \mathrm{~Hz}), 1.22(\mathrm{~d}, 3 \mathrm{H}, J=12.5 \mathrm{~Hz}), 1.57(\mathrm{~m}, 2 \mathrm{H}), 4.17(\mathrm{qt}, 1 \mathrm{H}, J=5.01 \mathrm{~Hz}), 7.23(\mathrm{t}, 1 \mathrm{H}$, $J=6.33 \mathrm{~Hz}), 7.31(\mathrm{~m}, 1 \mathrm{H}), 7.57(\mathrm{~m}, 3 \mathrm{H}), 7.80(\mathrm{~m}, 1 \mathrm{H}), 7.89(\mathrm{t}, 1 \mathrm{H}, J=7.44 \mathrm{~Hz}), 8.02(\mathrm{br}$ s, $1 \mathrm{H}), 8.27(\mathrm{~d}, 1 \mathrm{H}, J=5.78 \mathrm{~Hz}) .{ }^{13} \mathrm{C}$ NMR: $\delta 10.47,20.48,29.68,47.12,116.12(\mathrm{~d}, J=$ $21.12 \mathrm{~Hz}), 123.68(\mathrm{~d}, J=6.55 \mathrm{~Hz}), 126.90(\mathrm{~d}, J=11.20 \mathrm{~Hz}), 129.16,129.89 \& 131.89(\mathrm{~d}$, $J=12.00 \mathrm{~Hz}), 132.06,132.14,134.56,150.76,153.58,158.64,161.13 ; 162.06,164.98 .{ }^{19} \mathrm{~F}$ NMR: $\delta-113.11$. HRMS calcd for $\mathrm{C}_{19} \mathrm{H}_{19} \mathrm{FN}_{3} \mathrm{O}[M+\mathrm{H}]^{+}, 324.1512$; found, 324.1509.

(R)-N-(sec-Butyl)-4-(3-fluorophenyl)-quinazoline-2-carboxamide (5b)--General method $2 \mathrm{~b}$ was used with 3 -fluorophenyl boronic acid $(0.251 \mathrm{~g}, 1.8 \mathrm{mmol})$ to give $\mathbf{5 b}$ as a white powder $(0.28 \mathrm{~g}$, yield $86 \%)$. Mp: $90-91{ }^{\circ} \mathrm{C} .{ }^{1} \mathrm{H} \mathrm{NMR}\left(\mathrm{CDCl}_{3}\right): \delta 1.00(\mathrm{t}, 3 \mathrm{H}, J=7.10$ $\mathrm{Hz}), 1.31(\mathrm{~d}, 3 \mathrm{H}, J=12.2 \mathrm{~Hz}), 1.67(\mathrm{~m}, 2 \mathrm{H}), 4.25(\mathrm{qt}, 1 \mathrm{H}, J=5.05 \mathrm{~Hz}), 7.35(\mathrm{t}, 1 \mathrm{H}, J=6.23$ $\mathrm{Hz}), 7.55(\mathrm{~m}, 3 \mathrm{H}), 7.72(\mathrm{~m}, 1 \mathrm{H}), 7.98(\mathrm{t}, 1 \mathrm{H}, J=6.51 \mathrm{~Hz}), 8.00(\mathrm{br} \mathrm{s}, 1 \mathrm{H}), 8.01(\mathrm{~d}, 1 \mathrm{H}, J=$ $7.50 \mathrm{~Hz}), 8.36(\mathrm{~d}, 1 \mathrm{H}, J=6.0 \mathrm{~Hz}) .{ }^{13} \mathrm{C}$ NMR: $\delta 10.50,20.49,29.69,47.17,117.15,117.37$ (d, $J=12.45 \mathrm{~Hz}), 122.81,125.97$ (d, $J=11.82 \mathrm{~Hz}), 129.29,130.19 ; 130.29,130.37,134.49$, 138.76, 151.39, 153.40, 152.39 (d, $J=245.0 \mathrm{~Hz}), 161.54,162.06,164.01,167.38 .{ }^{19} \mathrm{~F}$ NMR: $\delta$-111.89. HRMS: calcd for $\mathrm{C}_{19} \mathrm{H}_{19} \mathrm{FN}_{3} \mathrm{O}[M+\mathrm{H}]^{+}, 324.1512$; found, 324.1518 .

(R)-(N-sec-Butyl)-4-(4-fluorophenyl)-quinazoline-2-carboxamide (5c).-General method $2 \mathrm{~b}$ was used with 4-fluorophenyl boronic acid $(0.251 \mathrm{~g}, 1.8 \mathrm{mmol})$ to give $\mathbf{5 c}$ as a white powder $(0.26 \mathrm{~g}$, yield $82 \%)$. Mp $96-97{ }^{\circ} \mathrm{C} .{ }^{1} \mathrm{H}$ NMR: $\delta 0.94(\mathrm{t}, 3 \mathrm{H}, J=7.4 \mathrm{~Hz}), 1.23$ $(\mathrm{d}, 3 \mathrm{H}, J=6.5 \mathrm{~Hz}), 1.59(\mathrm{~m}, 2 \mathrm{H}), 4.18(\mathrm{qt}, 1 \mathrm{H} J=7.2 \mathrm{~Hz}), 7.22(\mathrm{t}, 2 \mathrm{H}, J=7.5 \mathrm{~Hz}), 7.63$ (t, $1 \mathrm{H}, J=7.6 \mathrm{~Hz}), 7.77(\mathrm{~m}, 2 \mathrm{H}), 7.88(\mathrm{t}, 1 \mathrm{H}, J=7.5 \mathrm{~Hz}), 8.01$ (br. s, $1 \mathrm{H}), 8.01(\mathrm{~d}, 1 \mathrm{H}$, $J=7.6 \mathrm{~Hz}), 8.27(\mathrm{~d}, 1 \mathrm{H}, J=8.46 \mathrm{~Hz}) .{ }^{13} \mathrm{C}$ NMR: $\delta 10.48,20.49,29.69,47.12,115.88(\mathrm{~d}$, $J=2.1 \mathrm{~Hz}), 122.85,126.46,126.92,127.02,122.46(\mathrm{~d}, J=27.1 \mathrm{~Hz}), 130.15,131.31(\mathrm{~d}, J$ $=33.2 \mathrm{~Hz}), 134.34,152.38(\mathrm{~d}, J=203.1 \mathrm{~Hz}), 162.15,162.91,165.41,167.68 .{ }^{19} \mathrm{~F}$ NMR: $\delta$ -109.84. HRMS: calcd for $\mathrm{C}_{19} \mathrm{H}_{19} \mathrm{FN}_{3} \mathrm{O}[M+\mathrm{H}]^{+}, 324.1512$; found, 324.1509.

(R)-(N-sec-Butyl)-4-(2-(trifluoromethyl)phenyl)quinazoline-2-carboxamide (5d). -General method 2b was used with 2-(trifluoromethyl)phenyl boronic acid (0.342 g, 1.8 $\mathrm{mmol})$ to give $\mathbf{5 d}$ as a white powder $(0.23 \mathrm{~g}$, yield $65 \%)$. Mp $86-88{ }^{\circ} \mathrm{C} .{ }^{1} \mathrm{H}$ NMR: $\delta 0.89(\mathrm{t}$, $3 \mathrm{H}, J=7.15 \mathrm{~Hz}), 1.19(\mathrm{~d}, 3 \mathrm{H}, J=12.5 \mathrm{~Hz}), 1.54(\mathrm{~m}, 2 \mathrm{H}), 4.16(\mathrm{qt}, 1 \mathrm{H}, J=5.01 \mathrm{~Hz}), 7.43$ $(\mathrm{t}, 1 \mathrm{H}, J=6.33 \mathrm{~Hz}), 7.58(\mathrm{~m}, 2 \mathrm{H}), 7.66(\mathrm{t}, 2 \mathrm{H}, J=7.01 \mathrm{~Hz}), 7.87(\mathrm{~d}, 1 \mathrm{H}, J=6.41 \mathrm{~Hz}), 7.92$ $(\mathrm{t}, 1 \mathrm{H}, J=7.44 \mathrm{~Hz}), 8.04$ (br s, $1 \mathrm{H}), 8.32(\mathrm{~d}, 1 \mathrm{H}, J=5.78 \mathrm{~Hz}) .{ }^{13} \mathrm{C}$ NMR: $\delta 10.18 \& 10.41$, 
$20.28 \& 20.47,29.55 \& 29.64,47.07,123.68,123.69$ (qd, $J=273.66 \mathrm{~Hz}), 126.58,127.14$, $129.14,129.59$ (qd, $J=31.8 \mathrm{~Hz}$ ), 129.81, $130.15 \& 130.19,131.19 \& 131.46,134.63$, $134.95,151.04 \& 151.10,152.93 \& 152.99,161.90,167.39 .{ }^{19} \mathrm{~F}$ NMR $\delta-57.53 \&-57.55$. HRMS: calcd for $\mathrm{C}_{20} \mathrm{H}_{19} \mathrm{~F}_{3} \mathrm{~N}_{3} \mathrm{O}[M+\mathrm{H}]^{+}, 374.1480$; found, 374.1473 .

(R)-(N-sec-Butyl)-4-(3-(trifluoromethyl)phenyl)quinazoline-2-carboxamide (5e). -General method 2b was used with 3-(trifluoromethyl)phenyl boronic acid (0.342 g, 1.8 mmol) to give 5e as a white powder $(0.29 \mathrm{~g}$, yield $78 \%)$. Mp $91-93{ }^{\circ} \mathrm{C} .{ }^{1} \mathrm{H}$ NMR: $\delta 0.93(\mathrm{t}$, $3 \mathrm{H}, J=7.2 \mathrm{~Hz}), 1.24(\mathrm{~d}, 3 \mathrm{H}, J=12.5 \mathrm{~Hz}), 1.59(\mathrm{~m}, 2 \mathrm{H}), 4.18(\mathrm{~m} \mathrm{1H}), 7.65(\mathrm{~m}, 2 \mathrm{H}), 7.80(\mathrm{~d}$, $2 \mathrm{H}, J=7.5 \mathrm{~Hz}), 7.92(\mathrm{~d}, 2 \mathrm{H}, J=7.33 \mathrm{~Hz}), 7.95(\mathrm{~d}, 1 \mathrm{H}, J=7.1 \mathrm{~Hz}), 7.96(\mathrm{br} \mathrm{s}, 1 \mathrm{H}), 8.01(\mathrm{~m}$, $1 \mathrm{H}), 8.28(\mathrm{~d}, 1 \mathrm{H}, J=7.25 \mathrm{~Hz}) .{ }^{13} \mathrm{C}$ NMR: $\delta 10.45,20.46,29.67,47.19,122.82,123.81(\mathrm{qd}$, $J=272.65 \mathrm{~Hz}), 126.43,126.88,126.92(\mathrm{qd}, J=3.01 \mathrm{~Hz}), 129.3,129.51,130.24,131.29(\mathrm{qd}$, $J=33.20 \mathrm{~Hz}), 133.40,134.62,137.55,151.33,153.47,161.98 ; 167.35 .{ }^{19} \mathrm{~F}$ NMR: $\delta-63.72$. HRMS: calcd for $\mathrm{C}_{20} \mathrm{H}_{19} \mathrm{~F}_{3} \mathrm{~N}_{3} \mathrm{O}[M+\mathrm{H}]^{+}, 374.1480$; found, 374.1477 .

(R)-(N-sec-Butyl)-4-(4-(trifluoromethyl)phenyl)quinazoline-2-carboxamide (5f). -General method 2b was used with 4-(trifluoromethyl)phenyl boronic acid (0.342 g, 1.8 mmol) to give $5 \mathrm{f}$ as a white powder $(0.33 \mathrm{~g}$, yield $89 \%)$. Mp $81-82{ }^{\circ} \mathrm{C} .{ }^{1} \mathrm{H}$ NMR: $\delta 0.93(\mathrm{t}$, $3 \mathrm{H}, J=7.10 \mathrm{~Hz}), 1.23(\mathrm{~d}, 3 \mathrm{H}, J=11.63 \mathrm{~Hz}), 1.59(\mathrm{~m}, 2 \mathrm{H}), 4.18(\mathrm{~m} \mathrm{1H}), 7.65(\mathrm{~m}, 1 \mathrm{H}), 7.81$ $(\mathrm{d}, 2 \mathrm{H}, J=7.21 \mathrm{~Hz}), 7.87(\mathrm{~d}, 2 \mathrm{H}, J=7.11 \mathrm{~Hz}), 7.95\left(\mathrm{dt}, 2 \mathrm{H}, J_{1}=7.33 \mathrm{~Hz}, J_{2}=5.41 \mathrm{~Hz}\right)$, 8.01 (br s, $1 \mathrm{H}), 8.02$ (d, $2 \mathrm{H}, J=6.98 \mathrm{~Hz}), 8.29$ (d, $1 \mathrm{H}, J=7.07 \mathrm{~Hz}) .{ }^{13} \mathrm{C}$ NMR: $\delta 10.48$, 20.48, 29.69, 47.17, 122.65 (qd, $J=271.29 \mathrm{~Hz}), 125.22,125.61$ (qd, $J=3.10 \mathrm{~Hz}), 126.50$, $129.44,130.40$ (qd, $J=31.10 \mathrm{~Hz}$ ), 131.28, 132.22, 134.62, 140.19, 151.28, 152.40, 161.96, 167.42. ${ }^{19}$ F NMR: $\delta-63.72$. HRMS: calcd for $\mathrm{C}_{20} \mathrm{H}_{19} \mathrm{~F}_{3} \mathrm{~N}_{3} \mathrm{O}[M+\mathrm{H}]^{+}, 374.1480$; found, 374.1475 .

tert-Butyl (R)-(3-(2-(sec-Butyl(methyl)carbamoyl)quinazolin-4yl)phenyl)carbamate (6).-General method $2 \mathrm{~b}$ was used with 3 -( $N$-Boc-amino)phenyl boronic acid $(0.259 \mathrm{~g}, 1.8 \mathrm{mmol})$ to give $\mathbf{6}$ as an off-white powder $(0.336 \mathrm{~g}$, yield $77 \%)$. Mp: $147-150{ }^{\circ} \mathrm{C} .{ }^{1} \mathrm{H}$ NMR: $\delta 0.87$ and $1.03(\mathrm{t}, 3 \mathrm{H}, J=7.40 \mathrm{~Hz}), 1.25(\mathrm{~d}, 3 \mathrm{H}, J=7.33 \mathrm{~Hz})$, $1.43-1.71(\mathrm{~m}, 2 \mathrm{H}), 1.52 \& 1.67(\mathrm{~s}, 9 \mathrm{H}), 2.82 \& 3.02(\mathrm{~s}, 3 \mathrm{H}), 3.55 \& 4.84(\mathrm{~m}, 1 \mathrm{H}), 6.64(\mathrm{~s}$, $1 \mathrm{H}), 7.46(\mathrm{~m}, 2 \mathrm{H}), 7.64(\mathrm{~m}, 2 \mathrm{H}), 7.78(\mathrm{~d}, 1 \mathrm{H}, J=13.52 \mathrm{~Hz}), 7.95(\mathrm{~m}, 1 \mathrm{H}), 8.13(\mathrm{~m}, 2 \mathrm{H})$. ${ }^{13} \mathrm{C}$ NMR (acetone- $d_{6}$ ): $\delta 11.05 \& 11.09,18.46 \& 17.19,25.76,26.64 \& 27.25,29.80,55.74$ $\& 50.02,80.89,119.82,121.97 \& 122.02,122.98,127.14,128.29,129.14 \& 129.20,134.13$, $137.53 \& 137.50,138.82 \& 138.78,151.09 \& 151.04,152.65,158.62,167.53 \& 167.82$, 168.69 \& 168.77. HRMS: calcd for $\mathrm{C}_{25} \mathrm{H}_{35} \mathrm{~N}_{4} \mathrm{O}_{3}[\mathrm{M}+\mathrm{H}]^{+}, 435.2396$; found, 435.2394 .

(R)-4-(3-Aminophenyl)-N-(sec-butyl)-N-methylquinazoline-2-carboxamide (7).Compound 6 (300 $\mathrm{mg}, 0.70 \mathrm{mmol}$ ) was dissolved in DCM (2 mL) in a $25 \mathrm{~mL}$ flask. TFA $(2 \mathrm{~mL}$ ) was added, and the resulting mixture was sonicated for $3 \mathrm{~min}$ at RT, at which point TLC showed no remaining starting material. The solution was quenched with potassium carbonate slowly until the $\mathrm{pH}$ became greater than 8 . Then DCM $(10 \mathrm{~mL})$ was added. The mixture was washed with water $(2 \times 10 \mathrm{~mL})$ and then brine $(10 \mathrm{~mL})$. The organic phase was dried over $\mathrm{MgSO}_{4}$, evaporated to dryness, and purified over silica gel hexane/DCM/AcOEt/ $\mathrm{NEt}_{3}$ (25:15:60:0.01 by vol) to afford 7 as a yellow powder (226 mg, yield 97\%). Mp: 
161-163 ${ }^{\circ} \mathrm{C} .{ }^{1} \mathrm{H}$ NMR: $\delta 0.87 \& 1.04(\mathrm{t}, 3 \mathrm{H}, J=7.38 \mathrm{~Hz}), 1.24 \& 1.27\left(\mathrm{~d}, 3 \mathrm{H}, J_{M}=6.26\right.$, $\left.J_{m}=6.79 \mathrm{~Hz}\right), 1.40-1.62(\mathrm{~m}, 2 \mathrm{H}), 3.04 \& 2.82(\mathrm{~s}, 3 \mathrm{H}), 3.54 \& 4.84(\mathrm{~m}, 1 \mathrm{H}), 6.87,(\mathrm{~m}, 1 \mathrm{H})$, $7.11(\mathrm{~m}, 2 \mathrm{H}), 7.33(\mathrm{t}, 1 \mathrm{H}, J=7.4 \mathrm{~Hz}), 7.63(\mathrm{t}, 1 \mathrm{H}, J=7.01 \mathrm{~Hz}), 7.92(\mathrm{t}, 1 \mathrm{H}, J=7.92 \mathrm{~Hz})$, $8.16(\mathrm{~m}, 1 \mathrm{H}), 8.22(\mathrm{~m}, 1 \mathrm{H}) .{ }^{13} \mathrm{C}$ NMR: $\delta 11.11 \& 11.07,18.45 \& 17.18,25.74,26.65 \&$ $27.26,29.76,55.67 \& 49.94,116.46 \& 116.49,116.79,120.60 \& 120.56,122.35,127.38 \&$ $128.00,129.09,129.12 \& 129.35,134.01,137.81,146.82 \& 151.73,167.88,169.37$. HRMS: calcd for $\mathrm{C}_{20} \mathrm{H}_{23} \mathrm{~N}_{4} \mathrm{O}[M+\mathrm{H}]^{+}$, 335.1872; found, 335.1866.

(R)-N-(sec-Butyl)-4-(3-iodophenyl)-N-methylquinazoline-2-carboxamide (8)-To a solution of amino compound $7(200 \mathrm{mg}, 0.45 \mathrm{mmol})$ in $\mathrm{MeCN}(3 \mathrm{~mL})$ at $0{ }^{\circ} \mathrm{C}$ was added $p$-toluenesulfonic acid monohydrate $(327 \mathrm{mg}, 1.2 \mathrm{mmol})$, and the mixture was stirred at $0{ }^{\circ} \mathrm{C}$ for $10 \mathrm{~min}$. A solution containing $\mathrm{NaNO}_{2}(289 \mathrm{mg}, 4.19 \mathrm{mmol})$ and $\mathrm{KI}(146 \mathrm{mg}$, $0.88 \mathrm{mmol})$ in water $(0.3 \mathrm{~mL})$ was then added dropwise over $10 \mathrm{~min}$. The mixture was then allowed to warm to RT and stirred overnight. The resulting dark solution was diluted with water $(5 \mathrm{~mL})$, treated with a solution of saturated sodium metabisulfite $(5 \mathrm{~mL})$, and then extracted with DCM $(3 \times 15 \mathrm{~mL})$. The organic phases were combined, dried over $\mathrm{MgSO}_{4}$, and evaporated to dryness. The residue was purified by chromatography on silica gel with hexane/DCM/AcOEt/NEt 3 (35:25:40:0.01 by vol) to give 8 as an off-white powder (195 mg, yield 73\%). Mp: $175-177{ }^{\circ} \mathrm{C} .{ }^{1} \mathrm{H}-\mathrm{NMR}\left(\mathrm{CDCl}_{3}\right): \delta 0.87 \& 1.04(\mathrm{t}, 3 \mathrm{H}, J=7.37 \mathrm{~Hz}), 1.24$ $\& 1.27\left(\mathrm{~d}, 3 \mathrm{H}, J_{M}=6.60 \mathrm{~Hz}, J_{m}=6.81 \mathrm{~Hz}\right), 1.43-1.70(\mathrm{~m}, 2 \mathrm{H}), 2.82 \& 3.03(\mathrm{~s}, 3 \mathrm{H})$, $3.54 \& 4.84(\mathrm{~m}, 1 \mathrm{H}), 7.31(\mathrm{t}, 1 \mathrm{H}, J=7.82 \mathrm{~Hz}), 7.67(\mathrm{~m}, 1 \mathrm{H}), 7.76(\mathrm{~m}, 1 \mathrm{H}), 7.95(\mathrm{~m}, 2 \mathrm{H})$, $8.10(\mathrm{~m}, 1 \mathrm{H}), 8.15(\mathrm{~m}, 2 \mathrm{H}) .{ }^{13} \mathrm{C}$ NMR: $\delta 11.09 \& 11.05,18.46 \& 17.21,27.24 \& 25.78$, $26.64 \& 29.79,55.75 \& 50.03,94.29 \& 94.25,122.07 \& 122.10,126.60 \& 126.63,128.55$, $129.35,129.40,129.43,130.16,134.32,138.72,138.77 \& 139.12,151.11 \& 151.16,158.66$ \& 158.69, 167.38 \& 167.23, 167.63. HRMS: calcd for $\mathrm{C}_{20} \mathrm{H}_{21} \mathrm{~N}_{3} \mathrm{OI}[\mathrm{M}+\mathrm{H}]^{+}, 446.0729$; found, 446.0726 .

\section{(R)-(3-(2-(sec-Butyl(methyl)carbamoyl)quinazolin-4-yl)phenyl) (mesityl)iodonium Trifluoromethanesulfonate (9).-Iodoarene}

$8(112 \mathrm{mg}, 0.25 \mathrm{mmol}$ ) was stirred with triflic acid (4 equiv) in DCM $(1 \mathrm{~mL})$ for $5 \mathrm{~min}$ at RT within a $25 \mathrm{~mL}$ flask. Mesitylene (33.0 mg, $0.275 \mathrm{mmol}$ ) and $m$ CPBA ( $75.5 \mathrm{mg}, 0.44 \mathrm{mmol}$ ) were added, and the solution was stirred at $60{ }^{\circ} \mathrm{C}$ for $30 \mathrm{~min}$. The crude mixture was cooled to RT, concentrated in vacuo, and diluted with $\mathrm{Et}_{2} \mathrm{O}(1-3 \mathrm{~mL})$. The resultant precipitate was collected by filtration, washed with $\mathrm{Et}_{2} \mathrm{O}$, and then subjected to chromatography on a small column packed with basic alumina eluted with DCM/MeOH (20:1 v/v).

The eluted product was concentrated in vacuo to give the deprotonated product 9 as a beige powder (82 mg, yield $41 \%)$. Mp: $122-125{ }^{\circ} \mathrm{C} .[a]^{23} \mathrm{D}=-4.2(c=0.1) .{ }^{1} \mathrm{H}-\mathrm{NMR}\left(\mathrm{CDCl}_{3}\right)$ : $\delta 0.86 \& 1.04(\mathrm{t}, 3 \mathrm{H}, J=7.37 \mathrm{~Hz}), 1.24 \& 1.27\left(\mathrm{~d}, 3 \mathrm{H}, J_{M}=6.60 \mathrm{~Hz}, J_{m}=6.81 \mathrm{~Hz}\right)$, $1.41-1.63(\mathrm{~m}, 2 \mathrm{H}), 2.35(\mathrm{~s}, 3 \mathrm{H}), 2.65 \& 2.64(\mathrm{~s}, 6 \mathrm{H}), 2.80 \& 3.01(\mathrm{~s}, 3 \mathrm{H}), 3.51 \& 4.83(\mathrm{~m}$, 1H), 7.10 (s, 2H), $7.62(\mathrm{t}, 1 \mathrm{H}, J=7.82 \mathrm{~Hz}), 7.70(\mathrm{~m}, 1 \mathrm{H}), 7.90(\mathrm{~m}, 1 \mathrm{H}), 8.00(\mathrm{~m}, 3 \mathrm{H}), 8.15$ (m, 2H). ${ }^{13}$ C NMR: $\delta 10.04 \& 10.00,17.48 \& 16.22,20.14 \& 25.55,24.72 \& 28.76,26.10$, $16.17,26.20,54.78 \& 49.10,111.10,117.64,119.55 \& 119.46,120.70 \& 120.82,125.18$, $128.34 \& 128.32,129.50,131.36 \& 131.31,132.46 \& 132.52,133.25,133.52,133.81$ $\& 133.77,139.61,141.42 \& 141.49,143.69,150.12,157.42,164.83,166.46 \& 166.18 .{ }^{19} \mathrm{~F}$ NMR: $\delta-78.30$ (s). HRMS: calcd for $\mathrm{C}_{29} \mathrm{H}_{31} \mathrm{~N}_{3} \mathrm{OI}[M+\mathrm{H}]^{+}, 564.1512$; found, 564.1508. 


\section{Determination of TSPO Density in the Mouse and Rat Brain.}

The brain tissue was cut into small pieces (50-100 $\mathrm{mg}$ ) and placed in a $2 \mathrm{~mL}$ tube containing $1.4 \mathrm{~mm}$ ceramic beads and cold $\left(4^{\circ} \mathrm{C}\right)$ buffer $(5 \mathrm{mM}$ Tris-Base, $0.32 \mathrm{mM}$ sucrose, $1 \mathrm{mM}$ $\mathrm{MgCl}_{2}, \mathrm{pH} 7.4 ; 10$ times the weight of the tissue). The sample was processed in a bead mill homogenizer (Bead Ruptor Elite; Omni International, USA) at $4.85 \mathrm{~m} / \mathrm{s}$ for $20 \mathrm{~s}$. Membranes were suspended in a cold $\left(4^{\circ} \mathrm{C}\right)$ buffer $(50 \mathrm{mM}$ Tris-Base, $140 \mathrm{mM} \mathrm{NaCl}$, $\left.1.5 \mathrm{mM} \mathrm{MgCl}_{2}, 5 \mathrm{mM} \mathrm{KCl}, 1.5 \mathrm{mM} \mathrm{CaCl}_{2}, \mathrm{pH} 7.4\right)$, and protein concentrations were determined in a spectrophotometer (Nanodrop; Marshall Scientific, Hampton, NH) from an absorbance of $280 \mathrm{~nm}$. Then the aliquots were stored at $-80{ }^{\circ} \mathrm{C}$ until use.

Binding assays were performed as reported ${ }^{24}$ Briefly, aliquots of membrane suspension (about $250 \mathrm{mg}$ protein $/ \mathrm{mL}$ ) were prepared using an assay buffer (50 mM Tris-Base, 140 $\mathrm{mM} \mathrm{NaCl}, 1.5 \mathrm{mM} \mathrm{MgCl}_{2}, 5 \mathrm{mM} \mathrm{KCl}, 1.5 \mathrm{mM} \mathrm{CaCl}_{2}, \mathrm{pH} \mathrm{7.4,} 37^{\circ} \mathrm{C}$ ) and incubated with $\left[{ }^{3} \mathrm{H}\right] \mathrm{PK} 11195$ (molar activity $=3.11 \mathrm{GBq} / \mu \mathrm{mol}$, radioactivity concentration $=37 \mathrm{MBq} / \mathrm{mL}$, $K_{\mathrm{D}}=29 \mathrm{nM}$; Perkin Elmer) in a final volume of $250 \mu \mathrm{L}$ for $60 \mathrm{~min}$. Each assay vial contained $1 \mathrm{mg} / \mathrm{mL}$ of protein and $\left[{ }^{3} \mathrm{H}\right] \mathrm{PK} 11195(5.9 \mathrm{nM}$ ) with unlabeled PK11195 (eight concentrations ranging from $0.01 \mathrm{nM}$ to $10 \mu \mathrm{M}$ ). Incubations were terminated by filtration through GF/C filters (Whatman, Maidstone, UK) followed by three washes with $1.4 \mathrm{mM}$ $\mathrm{MgCl}_{2}$ in $50 \mathrm{mM}$ Tris-Base (pH 7.4). Whatman GF/C filters were preincubated with $0.05 \%$ polyethyleneimine at $60 \mathrm{~min}$ before filtration. Scintillation fluid $(3 \mathrm{~mL} / \mathrm{vial}$; Ultima Gold MV; Perkin Elmer) was added, and vials were counted on a liquid scintillation counter (Tri-carb 2900; Perkin Elmer). Each point was performed in triplicate. $B_{\max }(\mathrm{fmol} / \mathrm{mg}$ protein) was determined using the Prism 5.0 software (GraphPad Software Inc., La Jolla, CA) by the following equation: ${ }^{59}$

$$
\begin{aligned}
B_{\max }=(\text { top }- \text { bottom }) / \text { fractional occupancy } \\
=(\text { top }- \text { bottom }) /\left([\mathrm{L}] /\left([\mathrm{L}]+K_{\mathrm{D}}\right)\right)
\end{aligned}
$$

where $[\mathrm{L}]=$ radioligand concentration .

\section{Assay of Ligands for Affinity to TSPO in Rat Kidney and Human U87MG Cell Membranes.}

Inhibitory constants $\left(K_{\mathrm{i}}\right.$ 's) for the test ligands $\mathbf{3 a}-\mathbf{3 f}$ at the PK11195 binding site of TSPO were determined by radioligand binding displacement assays, as previously described. ${ }^{60,61}$ Such experiments were performed using the rat kidney and human U87MG cell line, chosen as TSPO-rich sources. Briefly, membrane homogenates from rat kidney or U87MG cells (30 and $20 \mu \mathrm{g}$ of protein, respectively) were incubated with increasing concentrations of the test ligand and [ $\left.{ }^{3} \mathrm{H}\right] \mathrm{PK} 11195$ (1 nM; molar activity, $3.17 \mathrm{MBq} / \mathrm{nmol}$; Perkin-Elmer Life Sciences) in an assay buffer (Tris-HCl $50 \mathrm{mM}, \mathrm{pH} 7.4$; final volume $500 \mu \mathrm{L}$ ) for $90 \mathrm{~min}$ at $0{ }^{\circ} \mathrm{C}$. To establish the nonspecific binding of $\left[{ }^{3} \mathrm{H}\right] \mathrm{PK} 11195$, samples were incubated in the presence of PK11195 ( $1 \mu \mathrm{M}$; solubilized with ethanol); the solvent concentration was less than $1 \%$ and did not interfere with the specific binding of the radioligand. At the end of incubation, samples were filtered rapidly under vacuum through $\mathrm{GF} / \mathrm{C}$ glass fiber filters (Sigma Aldrich). After being washed three times with a buffer (Tris- $\mathrm{HCl} 50 \mathrm{mM}$, $\mathrm{pH} 7.4 ; 3 \mathrm{~mL}$ ), the radioactivity trapped on the filter was measured by a liquid scintillation counter (TopCount; Perkin-Elmer Life and Analytical Sciences; 65\% counting efficiency). 
Competition displacement binding was fitted to sigmoidal (variable slope) curves using Prism 5.0 (GraphPad Software Inc., San Diego, CA). The concentration of test compounds that inhibited $\left[{ }^{3} \mathrm{H}\right] \mathrm{PK} 11195$ binding to kidney and U87MG cell membranes by $50 \%\left(\mathrm{IC}_{50}\right.$ values) obtained from the inhibition curves were converted to $K_{\mathrm{i}}$ values by the method of Cheng and Prusoff. ${ }^{62}$ In parallel experiments, PK11195 was tested as a positive control. The obtained $K_{\mathrm{i}}$ values of PK11195 for rat kidney and U87MG cells (3.40 \pm 0.35 and $2.90 \pm$ $0.14 \mathrm{nM}$, respectively) agreed with those reported previously. ${ }^{51,52}$

\section{Assay of Ligands for Affinity to Human Cerebellum TSPO Genotypes.}

Ligands 3a-3f were subjected to receptor binding assays in postmortem healthy human cerebellum homogenates with $\left[{ }^{3} \mathrm{H}\right] \mathrm{PK} 11195$ as the radioligand to characterize ligand binding sensitivities to TSPO polymorphism. Frozen human brain samples from three HAB subjects and three LAB subjects, whose affinity status had been predetermined by genotyping, were obtained from the Human Brain Collection Core (National Institute of Mental Health, NIMH) and used for measuring $K_{\mathrm{i}}$ values in triplicate from each subject. Binding assays with incubations for $1 \mathrm{~h}$ at $37{ }^{\circ} \mathrm{C}$ were performed as described previously. ${ }^{27}$ As a control in each assay, a self-displacement assay was used to calculate the $K_{\mathrm{D}}$ of PK11195. A mean $K_{\mathrm{D}}$ value of $4.35 \mathrm{nM}$ was then used as the dissociation constant for PK11195 to calculate the $K_{\mathrm{i}}$ value for the test ligand. ${ }^{51}$ A nonlinear regression curve-fitting software (GraphPad Prism 5; GraphPad Software, San Diego, CA) was used to fit data to a one-site model to provide ligand $K_{\mathrm{i}}$ values. ${ }^{51}$

\section{Radiochemistry.}

Production of NCA $\left[{ }^{11} \mathrm{C}\right]$ Carbon Dioxide.-NCA $\left[{ }^{11} \mathrm{C}\right]$ carbon dioxide $(\sim 85 \mathrm{GBq})$ was produced with a PETtrace cyclotron (GE Medical Systems, Milwaukee, WI) according to the ${ }^{14} \mathrm{~N}(\mathrm{p}, a){ }^{11} \mathrm{C}$ reaction ${ }^{63}$ by irradiation of nitrogen gas (initial pressure $160 \mathrm{psi} ; 75 \mathrm{~mL}$ volume) containing $1 \%$ oxygen with a proton beam $(16.5 \mathrm{MeV}, 45 \mu \mathrm{A})$ for $40 \mathrm{~min}$.

Production of $\left[{ }^{11} \mathrm{C}\right]$ lodomethane.-NCA $\left[{ }^{11} \mathrm{C}\right]$ iodomethane was produced within a hot cell from NCA $\left[{ }^{11} \mathrm{C}\right]$ carbon dioxide via reduction to $\left[{ }^{11} \mathrm{C}\right]$ methane and then vapor phase iodination. ${ }^{64}$ Thus, at the end of radionuclide production, $\left[{ }^{11} \mathrm{C}\right]$ carbon dioxide was delivered in the irradiated gas to a PETtrace MeI Process Module through a stainless tubing (OD 1/8 in., ID 1/16 in.) over $2 \mathrm{~min}$, trapped on molecular sieve (13X), and reduced to $\left[{ }^{11} \mathrm{C}\right]$ methane with hydrogen over nickel at $360{ }^{\circ} \mathrm{C}$. The $\left[{ }^{11} \mathrm{C}\right]$ methane was recirculated over iodine at 720 ${ }^{\circ} \mathrm{C}$ to generate $\left[{ }^{11} \mathrm{C}\right]$ iodomethane, which was trapped on Porapak $\mathrm{Q}$ held in the recirculation path.

Radiosynthesis of ${ }^{11} \mathrm{C}$-Labeled TSPO Ligands.-Each precursor $(2.0 \mu \mathrm{mol} ; 0.646$ $\mathrm{mg}$ for $\mathbf{5 a - 5 c}$ and $0.746 \mathrm{mg}$ for $\mathbf{5 d - 5 f})$ was placed in a reaction vial $(1 \mathrm{~mL}$ neck vial, Waters Corp.) with $t$-BuOK $(0.269 \mathrm{mg}, 2.4 \mu \mathrm{mol})$ under nitrogen, and the vial was septumsealed. At the end of cyclotron production of carbon-11 and preceding the production of $\left[{ }^{11} \mathrm{C}\right]$ iodomethane, DMSO $(0.40 \mathrm{~mL})$ was added to the vial and the mixture was shaken to give a light yellow solution. The vial was loaded into the hot-cell Synthia apparatus. 
$\left[{ }^{11} \mathrm{C}\right]$ Iodomethane (>37 GBq) was then swept into the vial with a stream of helium $(15$ $\mathrm{mL} / \mathrm{min}$ ) until radioactivity was maximal. The vial was placed in the oven of the Synthia apparatus and heated at $85{ }^{\circ} \mathrm{C}$ for $5 \mathrm{~min}$. The ${ }^{11} \mathrm{C}$-labeled ligand was separated with HPLC on an XTerra RP18 column $(7.8 \times 300 \mathrm{~mm}, 10 \mu \mathrm{m}$; Waters Corp., Columbia, MD) eluted at $6.5 \mathrm{~mL} / \mathrm{min}$ with $\mathrm{NH}_{4} \mathrm{OH}(10 \mathrm{mM}) / \mathrm{MeCN}\left(58: 42 \mathrm{v} / \mathrm{v}\right.$ for $\left[{ }^{11} \mathrm{C}\right] \mathbf{3 a},\left[{ }^{11} \mathrm{C}\right] \mathbf{3 c}$, and $\left[{ }^{11} \mathrm{C}\right] \mathbf{3 d}$; $56: 44 \mathrm{v} / \mathrm{v}$ for $\left[{ }^{11} \mathrm{C}\right] 3 \mathbf{b}$ and $\left[{ }^{11} \mathrm{C}\right] 3 \mathbf{e}$; and $57: 43 \mathrm{v} / \mathrm{v}$ for $\left.\left[{ }^{11} \mathrm{C}\right] \mathbf{3 f}\right)$. The eluate was monitored for radioactivity and absorbance at $254 \mathrm{~nm}$. Retention times were 18.8, 9.5, 10.8, 13.6, 15.1, and $17.1 \mathrm{~min}$ for $\left[{ }^{11} \mathrm{C}\right] \mathbf{3 a}-\left[{ }^{11} \mathrm{C}\right] \mathbf{3 f}$, respectively (see Supporting Information Figure S2 for representative radiochromatograms). The radioligand fraction was collected and then rotary evaporated to dryness $\left(80^{\circ} \mathrm{C}\right.$, water bath). The residue was dissolved in sterile saline for injection (USP; $10 \mathrm{~mL}$ ) containing ethanol (USP; $1 \mathrm{~mL}$ ). This solution was then passed through a sterile filter ( $0.2 \mu \mathrm{m}$ pore size, $25 \mathrm{~mm}$; Millex-MP, Millipore, Billerica, MA) into a sterile and pyrogen-free dose vial. Radiochemical yields of formulated radioligand from cyclotron-produced $\left[{ }^{11} \mathrm{C}\right]$ carbon dioxide were estimated to be $8,9,15,12,10$, and $14 \%$, respectively.

Production of $\left[{ }^{18} \mathrm{~F}\right]$ Fluoride lon.-NCA $\left[{ }^{18} \mathrm{~F}\right]$ fluoride ion was obtained through the ${ }^{18} \mathrm{O}(\mathrm{p}, \mathrm{n}){ }^{18} \mathrm{~F}$ nuclear reaction by irradiating $\left[{ }^{18} \mathrm{O}\right]$ water $(95$ atom \%) for 90 to $120 \mathrm{~min}$ with a proton beam $(17 \mathrm{MeV} ; 20 \mu \mathrm{A})$ generated with a PETtrace cyclotron. The aqueous $\left[{ }^{18} \mathrm{~F}\right]$ fluoride ion solution was taken to the hot-cell and dried in a modified ${ }^{65}$ Synthia apparatus. Thus, a solution of $\mathrm{K}_{2} \mathrm{CO}_{3}(0.28 \mathrm{mg}, 2 \mu \mathrm{mol})$ with $\mathrm{K} 2.2 .2(1.50 \mathrm{mg}, 4 \mu \mathrm{mol})$ in $\mathrm{MeCN} / \mathrm{H}_{2} \mathrm{O}(100 \mu \mathrm{L}, 9: 1 \mathrm{v} / \mathrm{v})$ and $\mathrm{MeCN}(200-400 \mu \mathrm{L})$ was added to a V-vial $(5 \mathrm{~mL}$; Alltech) containing $\left[{ }^{18} \mathrm{~F}\right]$ fluoride ion $(5.9-11 \mathrm{GBq})$ in $\left[{ }^{18} \mathrm{O}\right]$ water $(200-500 \mu \mathrm{L})$. The vial was then placed in an oven at $110^{\circ} \mathrm{C}$ and heated for 5 min under vacuum with a $\mathrm{N}_{2}$ gas flow $(100 \mathrm{~mL} / \mathrm{min})$ to remove the water-MeCN azeotrope. Three further cycles of $\mathrm{MeCN}$ ( 250 $\mu \mathrm{L})$ addition and evaporation were then performed. The dried $\left[{ }^{18} \mathrm{~F}\right]$ fluoride ion- $\mathrm{K}^{+}-\mathrm{K} 2.2 .2$ reagent was dissolved in DMF $(250 \mu \mathrm{L})$ in readiness for the labeling reaction.

Radiosynthesis of $\left[{ }^{\mathbf{1 8}} \mathrm{F}\right] \mathbf{3 b}$.- The aryl(mesityl)iodonium salt $\mathbf{9}(4.25 \mathrm{mg}, 6 \mu \mathrm{mol})$ was weighed into a $4 \mathrm{~mL}$ glass vial containing a stirrer bar and then dissolved in DMF (350 $\mu \mathrm{L})$. A stock solution of tetrakis(acetonitrile)copper(I) triflate was prepared $(14.3 \mathrm{mg}$ in $1 \mathrm{~mL}$ of DMF; $0.04 \mathrm{M})$. An aliquot of this solution $(150 \mu \mathrm{L} 6 \mu \mathrm{mol})$ was added to the vial containing 9. The reaction vial, having an atmosphere of ambient air, was sealed with a Teflon-silicone septum cap, and then the solution was thoroughly vortexed.

This solution of precursor 9 was then taken to the hot-cell and added from a syringe to the $5 \mathrm{~mL}$ vial containing the solution of the $\left[{ }^{18} \mathrm{~F}\right]$ fluoride ion- $\mathrm{K} 2.2 .2-\mathrm{K}_{2} \mathrm{CO}_{3}$ complex in $\operatorname{DMF}(250 \mu \mathrm{L})$. The stirred vial was then heated in an aluminum block at $95{ }^{\circ} \mathrm{C}$ for 20 $\mathrm{min}$. Alternatively, the $5 \mathrm{~mL}$ vial was heated in the hot-cell with microwave irradiation (2 $\times 90 \mathrm{~s}, 75-80 \mathrm{~W})$. The reaction was allowed to cool off. Then the mixture was dissolved in water $(1.0 \mathrm{~mL})$ and injected onto an XTerra RP18 column $(10 \mu \mathrm{m}, 7.8 \times 300 \mathrm{~mm}$; Waters $)$ for HPLC purification eluted at $6.5 \mathrm{~mL} / \mathrm{min}$ with aq. $\mathrm{NH}_{4} \mathrm{OH}(10 \mathrm{mM}) / \mathrm{MeCN}(70: 30 \mathrm{v} / \mathrm{v})$. $\left[{ }^{18} \mathrm{~F}\right] \mathbf{3 b}$ eluted with a retention time of $40.7 \mathrm{~min}$ (see Supporting Information Figure S3 for the representative chromatogram). This radioactive fraction was collected and then rotary evaporated to dryness $\left(80^{\circ} \mathrm{C}\right.$, water-bath). The residue was dissolved in ethanol (USP; 0.2 
$\mathrm{mL}$ ) and diluted with saline for injection (USP, $1.8 \mathrm{~mL}$ ). This solution was then passed through a sterile filter $(0.2 \mu \mathrm{m}$ pore size, $25 \mathrm{~mm}$; Millex-MP) into a sterile and pyrogen-free dose vial.

Analysis of Radioligands.-A sample of each formulated radioligand was analyzed for radiochemical and chemical purity with HPLC on a Luna C18 column $(4.6 \mathrm{~mm} \times 250 \mathrm{~mm}$, $5 \mu \mathrm{m}$; Phenomenex, Torrance, $\mathrm{CA}$ ) eluted for $15 \mathrm{~min}$ with aq. $\mathrm{NH}_{4} \mathrm{OH}(10 \mathrm{mM})$ in $\mathrm{MeCN}$ $(50: 50 \mathrm{v} / \mathrm{v})$ at $2.0 \mathrm{~mL} / \mathrm{min}$. The eluate was monitored for absorbance at $254 \mathrm{~nm}$ and for radioactivity (pin diode detector; Bioscan Inc., Washington, DC). A sample was analyzed similarly after being spiked with the reference ligand to check for coelution. Retention times were $13.5,8.6,8.0,10.1,10.7$, and $10.15 \mathrm{~min}$ for $\left[{ }^{11} \mathrm{C}\right] \mathbf{3 a}-\left[{ }^{11} \mathrm{C}\right] \mathbf{3 f}$, respectively $\left(\left[{ }^{18} \mathrm{~F}\right] \mathbf{3 b}\right.$ naturally has the same retention time as $\left[{ }^{11} \mathrm{C}\right] \mathbf{3 b}$ ) (see Supporting Information Figures $\mathrm{S} 4$ and S5 for representative chromatograms). Each formulated radioligand had greater than 98\% radiochemical purity. In each case, the response of the analytical system had been calibrated for the mass of the reference ligand to allow molar activity to be calculated. The stability of each formulated radioligand was also assessed with radio-HPLC at 1 and $2 \mathrm{~h}$ after radiosynthesis. Product identity was further affirmed after full radioactive decay by LC-MS/MS of the associated carrier on a Finnigan LCQ DECA instrument (ThermoFisher Scientific, Waltham, MD) fitted with a Luna C18 column ( $3 \mu \mathrm{m}, 50 \times 2 \mathrm{~mm}$; Phenomenex) eluted with a gradient of binary solvents (A/B;200 $\mu \mathrm{L} / \mathrm{min})$ composed of water/methanol/ acetic acid (90:10:0.5 by vol; A) and methanol/acetic acid (100:0.5, v/v; B). Following electrospray ionization (positive ion), the MS acquired ions ranging between $\mathrm{m} / \mathrm{z} 150$ and 750 .

\section{Computation of $\operatorname{cLog} D$.}

$\operatorname{cLog} D$ (at $\mathrm{pH}$ 7.4) values for ligands were computed with the Pallas for Windows software version 3.8 in default mode (CompuDrug International, Bal Harbor, FL).

\section{Measurement of $\log D$.}

$\log D$ (at $\mathrm{pH}$ 7.4) was measured on ligands 3a-3f by partition between $n$-octanol and the sodium phosphate buffer ( $\mathrm{pH}$ 7.4) at room temperature, as described in detail previously. ${ }^{14}$

\section{Stability of Radioligands in Buffer and in Whole Blood and Plasma In Vitro.}

The stability of radioligands to incubation in the sodium phosphate buffer $(0.15 \mathrm{M}, \mathrm{pH} 7.4)$ for 1 and $4 \mathrm{~h}$ at RT was assessed by reversed-phase HPLC on an Xterra column (7.8 $\times$ $300 \mathrm{~mm}, 10 \mu \mathrm{m}$; Waters Corp.) eluted at $4.0 \mathrm{~mL} / \mathrm{min}$ with methanol/water/triethylamine (85:20:0.1, by vol).

\section{Plasma Free Fraction Determinations.}

Free fractions $\left(f_{\mathrm{p}}\right)$ of $\left[{ }^{11} \mathrm{C}\right] \mathbf{3 a}-\left[{ }^{11} \mathrm{C}\right] \mathbf{3 f}$ in monkey and human plasma were determined by an ultrafiltration method, as previously described. ${ }^{66}$ 


\section{PET Imaging of Radioligands in Mice.}

PET Image Acquisition.-Wild-type FVB mice were purchased from Taconic Farm (Germantown, NY) for this study. For each scanning session, a group of six mice was set up to be imaged simultaneously in the same microPET Focus 120 camera (Siemens Medical Solution, Knoxville, TN), three mice at baseline and three mice pretreated with PK11195 $(5 \mathrm{mg} / \mathrm{kg})$ at $10 \mathrm{~min}$ before radioligand injection. Mice were anesthetized with $1.5 \%$ isoflurane and injected with the formulated radioligand $(100-150 \mu \mathrm{L})$ via a tail vein catheter at an infusion rate of $0.3 \mathrm{~mL} / \mathrm{min}$ from a six-syringe infusion pump (Braintree Scientific Inc., Braintree, MA). Body temperature was controlled using a heat lamp. Table S3 (Supplementary Information) summarizes the PET study parameter information, such as administered doses. For three of the six ${ }^{11} \mathrm{C}$-labeled ligands, a second imaging session was necessary to make up the animal loss due to death or failed tail vein catheter so that all groups have two or more animals. PET scans were acquired without blood sampling for 100 $\min$ for ${ }^{11} \mathrm{C}$-labeled ligands and $120 \mathrm{~min}$ for $\left[{ }^{18} \mathrm{~F}\right] \mathbf{3 b}$. Durations of acquisition frames were in the following sequence: $6 \times 20 \mathrm{~s}, 5 \times 60 \mathrm{~s}, 4 \times 120 \mathrm{~s}, 3 \times 300 \mathrm{~s}, 3 \times 600 \mathrm{~s}$, and $3 \times 1200 \mathrm{~s}$. Images were reconstructed using Fourier rebinning plus a two-dimensional OSEM algorithm without scatter and attenuation correction.

Data Analysis.-A two-dimensional whole brain ROI was drawn manually on five contiguous slices for each animal in the coronal image using PMOD 3.9 (PMOD Technology, Zurich, Switzerland). Decay corrected radioactivity in the ROI was calculated at standardized uptake value (SUV), which normalizes for the amount of injected radioactivity and animal body weight, according to the following equation:

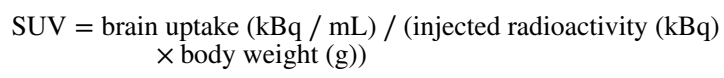

The time-activity curve of the whole-brain uptake was obtained as the mean SUV within the ROIs of each mouse and compared (midpoints of timeframes are plotted in time-activity curves). The blocking effect was calculated from the means of the brain uptake for the 80-100 min interval of imaging for baseline and blocked conditions. Negligible occupancy of TSPO by the carrier present in the radioligand at baseline was confirmed by estimating occupancy from the brain concentration and radioligand molar activity, assuming a $B_{\max }$ value of $341 \mathrm{fmol}$ per mg of protein for TSPO in mice. ${ }^{52}$

\section{Supplementary Material}

Refer to Web version on PubMed Central for supplementary material.

\section{ACKNOWLEDGMENTS}

We thank the NIH Clinical PET Center (Director: Dr. Peter Herscovitch) for carbon-11 and fluorine-18 production, the Human Brain Collection Core (NIMH, http://www.nimh.nih.gov/hbcc) for providing human brain tissue samples, and Dr. John Lloyd (NIDDK) for HRMS measurements. 
Funding

F.G.S., J.-H.L., C.L.M, I.S., S.S.Z., L.S.M., J.-S.L., R.L.G., R.M.D., X.Y., R.B.I., and V.W.P. were supported by the Intramural Research Program of NIH (National Institute of Mental Health; projects ZIA-MH002793 and ZIA-MH002795). B.C. and S.C. were supported by the Italian Ministero dell'Istruzione, dell'Università e della Ricerca (MIUR), Progetti di Ricerca di Interesse Nazionale (PRIN 2017MT3993).

\section{ABBREVIATIONS}

\begin{tabular}{|c|c|}
\hline$A_{\mathbf{m}}$ & molar activity \\
\hline DCE & 1,2-dichloroethane \\
\hline DCM & dichloromethane \\
\hline$f_{\mathbf{p}}$ & plasma free fraction \\
\hline HABs & high-affinity binders \\
\hline HPLC & high-performance liquid chromatography \\
\hline K 2.2.2 & 4,7,13,16,21,24-hexaoxa-1,10-diazabicyclo[8.8.8]hexacosane \\
\hline LABs & low-affinity binders \\
\hline MABs & mixed-affinity binders \\
\hline$m$ CPBA & $m$-chloroperbenzoic acid \\
\hline MIP & maximum intensity projection \\
\hline MRI & magnetic resonance image \\
\hline MW & microwave \\
\hline NCA & no-carrier-added \\
\hline PET & positron emission tomography \\
\hline NIDDK & National Institute of Diabetes and Digestive and Kidney Diseases \\
\hline NIMH & National Institute of Mental Health \\
\hline PyBroP & bromo-tris-pyrrolidino-phosphonium hexafluorophosphate \\
\hline $\mathbf{R C Y}$ & radiochemical yield \\
\hline RT & room temperature \\
\hline SNP & single nucleotide polymorphism \\
\hline SUV & standardized uptake value \\
\hline TLC & thin layer chromatography \\
\hline TSPO & translocator protein $18 \mathrm{kDa}$ \\
\hline
\end{tabular}




\section{REFERENCES}

(1). Meyer JH; Cervenka S; Kim M-J; Kreisl WC; Henter ID; Innis RB Neuroinflammation in psychiatric disorders: PET imaging and promising new targets. Lancet Psychiatry 2020, 7, 1064 1074. [PubMed: 33098761]

(2). Kreisl WC; Kim M-J; Coughlin JM; Henter ID; Owen DR; Innis RB PET imaging of neuroinflammation in neurological disorders. Lancet Neurology 2020, 19, 940-950. [PubMed: 33098803]

(3). Papadopoulos V; Baraldi M; Guilarte TR; Knudsen TB; Lacapere J-J; Lindemann P; Norenberg MD; Nutt D; Weizman A; Zhang M-R; Gavish M Translocator protein (18 kDa): new nomenclature for the peripheral-type benzodiazepine receptor based on its structure and molecular function. Trends Pharmacol. Sci 2006, 27, 402-409. [PubMed: 16822554]

(4). Doble A; Malgouris C; Daniel M; Daniel N; Imbault F; Basbaum A; Uzan A; Guérémy C; Le Fur G Labelling of peripheral-type benzodiazepine binding sites in human brain with $\left[{ }^{3} \mathrm{H}\right] \mathrm{PK} 11195$ : anatomical and subcellular distribution. Brain Res. Bull 1987, 18, 49-61. [PubMed: 3030512]

(5). Rone MB; Ran J; Papadopoulos V Cholesterol transport in steroid biosynthesis: role of proteinprotein interactions and implications in disease states. Biochim. Biophys. Acta 2009, 1791, 646658. [PubMed: 19286473]

(6). Papadopoulos V; Lecanu L; Brown RC; Han Z; Yao Z-X Peripheral-type benzodiazepine receptor in neurosteroid biosynthesis, neuropathology and neurological disorders. Neuroscience 2006, 138, 749-756. [PubMed: 16338086]

(7). Chaveau F; Boutin H; Van Camp N; Dollé F; Tavitian B Nuclear imaging of neuroinflammation: a comprehensive review of $\left[{ }^{11} \mathrm{C}\right] \mathrm{PK} 11195$ challengers. Eur. J. Nucl. Med. Mol. Imaging 2008, 35, 2304-2319. [PubMed: 18828015]

(8). Dollé F; Luus C; Reynolds A; Kassiou M Radiolabelled molecules for imaging the translocator protein (18 kDa) using positron emission tomography. Curr. Med. Chem 2009, 16, 2899-2923. [PubMed: 19689272]

(9). Schweitzer PJ; Fallon BA; Mann JJ; Kumar JSD PET tracers for the peripheral benzodiazepine receptor and uses thereof. Drug Discovery Today 2010, 15, 933-942. [PubMed: 20800696]

(10). Camsonne R; Moulin MA; Crouzel C; Syrota A; Maziere M; Comar D ${ }^{11}$ C-Labeling of PK 11195 and visualization of peripheral receptors of benzodiazepines by positron emission tomography. J. Pharmacol 1986, 17, 383.

(11). Shah F; Hume SP; Pike VW; Ashworth S; McDermott J Synthesis of the enantiomers of $\left[N\right.$-methyl $\left.{ }^{11} \mathrm{C}\right] \mathrm{PK} 11195$ and comparison of their behaviours as radioligands for PK binding sites in rats. Nucl. Med. Biol 1994, 21, 573-581. [PubMed: 9234314]

(12). Petit-Taboué MC; Baron JC; Barré L; Travere JM; Speckel D; Camsonne R; MacKenzie ET Brain kinetics and specific binding of $\left[{ }^{11} \mathrm{C}\right] \mathrm{PK} 11195$ to $\omega 3$ sites in baboon. Eur. J. Pharmacol 1991, 200, 347-351. [PubMed: 1782994]

(13). Kreisl WC; Fujita M; Fujimura Y; Kimura N; Jenko KJ; Kannan P; Hong J; Morse CL; Zoghbi SS; Gladding RL; Jacobson S; Oh U; Pike VW; Innis RB Comparison of $\left[{ }^{11} \mathrm{C}\right](R)$ PK 11195 and $\left[{ }^{11} \mathrm{C}\right] \mathrm{PBR} 28$, two radioligands for translocator protein $(18 \mathrm{kDa})$ in human and monkey: implications for positron emission tomographic imaging of this inflammation biomarker. NeuroImage 2010, 49, 2924-2932. [PubMed: 19948230]

(14). Briard E; Zoghbi SS; Imaizumi M; Gourley JP; Shetty HU; Hong J; Cropley V; Fujita M; Innis RB; Pike VW Synthesis and evaluation in monkey of two sensitive ${ }^{11} \mathrm{C}$-labeled aryloxyanilide ligands for imaging brain peripheral benzodiazepine receptors in vivo. J. Med. Chem 2008, 51, 17-30. [PubMed: 18067245]

(15). Imaizumi M; Briard E; Zoghbi SS; Gourley JP; Hong J; Fujimura Y; Pike VW; Innis RB; Fujita M Brain and whole-body imaging in nonhuman primates of $\left[{ }^{11} \mathrm{C}\right] \mathrm{PBR} 28$, a promising PET radioligand for peripheral benzodiazepine receptors. NeuroImage 2008, 39, 1289-1298. [PubMed: 18024084]

(16). Fujita M; Imaizumi M; Zoghbi SS; Fujimura Y; Farris AG; Suhara T; Hong J; Pike VW; Innis RB Kinetic analysis in healthy humans of a novel positron emission tomography radioligand 
to image the peripheral benzodiazepine receptor, a potential biomarker for inflammation.

NeuroImage 2008, 40, 43-52. [PubMed: 18093844]

(17). Endres CJ; Pomper MG; James M; Uzuner O; Hammoud DA; Watkins CC; Reynolds A; Hilton J; Dannals RF; Kassiou M Initial evaluation of [ $\left.{ }^{11} \mathrm{C}\right] \mathrm{DPA}-713$, a novel TSPO PET ligand, in humans. J. Nucl. Med 2009, 50, 1276-1282. [PubMed: 19617321]

(18). Briard E; Zoghbi SS; Siméon F; Imaizumi M; Gourley JP; Shetty HU; Lu S-Y; Fujita M; Innis RB; Pike VW Singlestep high-yield radiosynthesis and evaluation of a selective ${ }^{18}$ F-labeled ligand for imaging brain peripheral benzodiazepine receptors with PET. J. Med. Chem 2009, 52, 688-699. [PubMed: 19119848]

(19). Wilson AA; Garcia A; Parkes J; McCormick P; Stephenson KA; Houle S; Vasdev $\mathrm{N}$ Radiosynthesis and initial evaluation of $\left[{ }^{18} \mathrm{~F}\right] \mathrm{FEPPA}$ for PET imaging of peripheral benzodiazepine receptors. Nucl. Med. Biol 2008, 35, 305-314. [PubMed: 18355686]

(20). Owen DR; Yeo AJ; Gunn RN; Song K; Wadsworth G; Lewis A; Rhodes C; Pulford DJ; Bennacef I; Parker CA; StJean PL; Cardon LR; Mooser VE; Matthews PM; Rabiner EA; Rubio JP An $18-\mathrm{kDa}$ translocator protein (TSPO) polymorphism explains differences in binding affinity of the PET radioligand PBR28. J. Cereb. Blood Flow Metab 2012, 32, 1-5. [PubMed: 22008728]

(21). Guo Q; Colasanti A; Owen DR; Onega M; Kamalakaran A; Bennacef I; Matthews PM; Rabiner EA; Turkheimer FE; Gunn RN Quantification of the specific translocator protein signal of ${ }^{18}$ F-PBR111 in healthy humans: a genetic polymorphism effect on in vivo binding. J. Nucl. Med 2013, 54, 1915-1923. [PubMed: 24071511]

(22). Mizrahi R; Rusjan PM; Kennedy J; Pollock B; Mulsant B; Suridjan I; De Luca V; Wilson AA; Houle $\mathrm{S}$ Translocator protein $(18 \mathrm{kDa})$ polymorphism (rs6971) explains in-vivo brain binding affinity of the PET radioligand $\left[{ }^{18}\right.$ F]-FEPPA. J. Cereb. Blood Flow Metab 2012, 32, 968-972. [PubMed: 22472607]

(23). Owen DRJ; Gunn RN; Rabiner EA; Bennacef I; Fujita M; Kreisl WC; Innis RB; Pike VW; Reynolds R; Matthews PM; Parker CA Mixed-affinity binding in humans with 18-kDa translocator protein ligands. J. Nucl. Med 2011, 52, 24-32. [PubMed: 21149489]

(24). Owen DR; Howell OW; Tang S-P; Wells LA; Bennacef I; Bergstrom M; Gunn RN; Rabiner EA; Wilkins MR; Reynolds R; Matthews PM; Parker CA Two binding sites for $\left[{ }^{3} \mathrm{H}\right] \mathrm{PBR} 28$ in human brain: implications for TSPO PET imaging of neuroinflammation. J. Cereb. Blood Flow Metab 2010, 30, 1608-1618. [PubMed: 20424634]

(25). Kreisl WC; Jenko KJ; Hines CS; Lyoo CH; Corona W; Morse CL; Zoghbi SS; Hyde T; Kleinman JE; Pike VW; McMahon FJ; Innis RB; Biomarkers Consortium PET Radioligand Project Team. A genetic polymorphism for translocator protein $18 \mathrm{kDa}$ affects both in vitro and in vivo radioligand binding in human brain to this putative biomarker of neuroinflammation. J. Cereb. Blood Flow Metab 2013, 33, 53-58. [PubMed: 22968319]

(26). Castellano S; Taliani S; Milite C; Pugliesi I; Da Pozzo E; Rizzetto E; Bendinelli S; Costa B; Cosconati S; Greco G; Novellino E; Sbardella G; Stefancich G; Martini C; Da Settimo F Synthesis and biological evaluation of 4-phenylquinazoline-2-carboxamides designed as a novel class of potent ligands of the translocator protein. J. Med. Chem 2012, 55, 4506-4510. [PubMed: 22489952]

(27). Zanotti-Fregonara P; Zhang Y; Jenko KJ; Gladding RL; Zoghbi SS; Fujita M; Sbardella G; Castellano S; Taliani S; Martini C; Innis RB; Da Settimo F; Pike VW Synthesis and evaluation of translocator $18 \mathrm{kDa}$ protein (TSPO) positron emission tomography (PET) radioligands with low binding sensitivity to human single nucleotide polymorphism rs6971. ACS Chem. Neurosci 2014, 5, 963-971. [PubMed: 25123416]

(28). Fujita M; Kobayashi M; Ikawa M; Gunn RN; Rabiner EA; Owen DR; Zoghbi SS; Haskali MB; Telu S; Pike VW; Innis RB Comparison of four ${ }^{11} \mathrm{C}$-labeled PET ligands to quantify translocator protein $18 \mathrm{kDa}$ (TSPO) in human brain: $(R)$-PK11195, PBR28, DPA-713, and ER176-based on recent publications that measured specific-to-non-displaceable ratios. EJNMMI Res. 2017, 7, 84. [PubMed: 29038960]

(29). Ikawa M; Lohith TG; Shrestha S; Telu S; Zoghbi SS; Castellano S; Taliani S; Da Settimo F; Fujita M; Pike VW; Innis RB; Biomarkers Consortium Radioligand Project Team. ${ }^{11}$ C-ER176, a radioligand for $18-\mathrm{kDa}$ translocator protein, has adequate sensitivity to robustly image all three affinity genotypes in human brain. J. Nucl. Med 2017, 58, 320-325. [PubMed: 27856631] 
(30). Hong J; Telu S; Zhang Y; Miller WH; Shetty HU; Morse CL; Pike VW Translation of ${ }^{11} \mathrm{C}$ labeled tracer synthesis to a CGMP environment as exemplified by $\left[{ }^{11} \mathrm{C}\right] \mathrm{ER} 176$ for PET imaging of human TSPO. Nat. Protoc 2021, 16, 4419-4445. [PubMed: 34363068]

(31). Dubroeucq M-C; Renault CLA; Le Fur GR Nouveaux dérivés d'arène et d'hétéroarènecarboxamides, leur procédé de préparation et médicaments les contenant. Eur. Patent 1983, 0094271B1.

(32). Castellano S; Taliani S; Viviano M; Milite C; Da Pozzo E; Costa B; Barresi E; Bruno A; Cosconati S; Marinelli L; Greco G; Novellino E; Sbardella G; Da Settimo F; Martini C Structureactivity relationship refinement and further assessment of 4-phenyl-quinazoline-2-carboxamide translocator protein ligands as antiproliferative agents in human glioblastoma tumors. J. Med. Chem 2014, 57, 2413-2428. [PubMed: 24580635]

(33). Pike VW Considerations in the development of reversibly binding PET radioligands for brain imaging. Curr. Med. Chem 2016, 23, 1818-1869. [PubMed: 27087244]

(34). Cai L; Lu S; Pike VW Chemistry with [ ${ }^{18}$ F]fluoride ion. Eur. J. Org. Chem 2008, 2853-2873.

(35). Pike VW Hypervalent aryliodine compounds as precursors for radiofluorination. J. Labelled Compd. Radiopharm 2017, 61, 196-227.

(36). Tredwell M; Preshlock SM; Taylor NJ; Gruber S; Huiban M; Passchier J; Mercier J; Gnicot $\mathrm{C}$; Gouverneur V A general copper-mediated ${ }^{18} \mathrm{~F}$ fluorination of arenes. Angew. Chem., Int. Ed 2014, 126, 7885-7889.

(37). Huiban M; Tredwell M; Mizuta S; Wan Z; Zhang X; Collier TL; Gouverneur V; Passchier J A broadly applicable $\left[{ }^{18} \mathrm{~F}\right]$ trifluoromethylation of aryl and heteroaryl iodides for PET imaging. Nat. Chem 2013, 5, 941-944. [PubMed: 24153372]

(38). van der Born D; Sewing C; Herscheid JDM; Windhorst AD; Orru RVA; Vugts DJ A universal procedure for the $\left[{ }^{18} \mathrm{~F}\right]$ trifluoromethylation of aryl iodides and aryl boronic acids with highly improved specific activity. Angew. Chem., Int. Ed 2014, 53, 11046-11050.

(39). Ivashkin P; Lemonnier G; Cousin J; Grégoire V; Labar D; Jubault P; Pannecouck X $\left[{ }^{18} \mathrm{~F}\right] \mathrm{CuCF}_{3}$ : A $\left[{ }^{18}\right.$ F $]$ trifluoromethylating agent for arylboronic acids and aryl iodides. Chem.-A Eur. J 2014, 20, 9514-9518.

(40). Yang BY; Telu S; Haskali MB; Morse CL; Pike VW A gas phase route to [ $\left.{ }^{18} \mathrm{~F}\right]$ fluoroform with limited molar activity dilution. Sci. Rep 2019, 9, 14835. [PubMed: 31619702]

(41). Pees A; Windhorst AD; Vosjan MJWD; Tadino V; Vugts DJ Synthesis of [ $\left.{ }^{18} \mathrm{~F}\right]$ fluoroform with high molar activity. Eur. J. Org. Chem 2020, 1177-1185.

(42). Haskali MB; Pike VW [ ${ }^{11}$ C]Fluoroform, a breakthrough for versatile labeling of PET radiotracer trifluoromethyl groups in high molar activity. Chem. - Eur. J 2017, 23, 8156-8160. [PubMed: 28514059]

(43). Young NJ; Pike VW; Taddei C Rapid and efficient synthesis of $\left[{ }^{11} \mathrm{C}\right]$ trifluoromethylarenes from primary aromatic amines and $\left[{ }^{11} \mathrm{C}_{\mathrm{CuCF}_{3}}\right.$. ACS Omega 2020, 5, 19557-19564. [PubMed: 32803050]

(44). Ramos-Torres KM; Zhou Y-P; Yang BY; Guehl NJ; Hyun MS; Telu S; Normandin MD; Pike VW; Brugarolas P Syntheses of $\left[{ }^{11} \mathrm{C}\right] 2$ - and $\left[{ }^{11} \mathrm{C}\right] 3$-trifluoromethyl-4-aminopyridine: potential PET radioligands for demyelinating diseases. RSC Med. Chem 2020, 11, 1161-1167. [PubMed: 33479620]

(45). Kang F-A; Sui Z; Murray WV Pd-Catalyzed direct arylation of tautomerizable heterocycles with aryl boronic acids via C-OH bond activation using phosphonium salts. J. Am. Chem. Soc 2008, 130, 11300-11302. [PubMed: 18665598]

(46). Higashiyama K; Fujikura H; Takahashi H Diastereoselective addition of chiral aliphatic imines and 2-alkyl-1,3-oxazolidines to organometallic reagents. Chem. Pharm. Bull 1995, 43, 722-728.

(47). Haider N; Nuß S Weinreb amidation as the cornerstone of an improved synthetic route to a ringmodified derivatives of luotonin A. Molecules 2012, 17, 11363-11378. [PubMed: 23011278]

(48). Lee Y-S; Siméon FG; Briard E; Pike VW Solution structures of the prototypical $18 \mathrm{kDa}$ translocator protein ligand, PK 11195 , elucidated with ${ }^{1} \mathrm{H} /{ }^{13} \mathrm{C}$ NMR spectroscopy and quantum chemistry. ACS Chem. Neurosci 2012, 3, 325-335. [PubMed: 22860199] 
(49). Shultz MD Setting expectations in molecular optimizations: strengths and limitations of commonly used composite parameters. Bioorg. Med. Chem. Lett 2013, 23, 5980-5991. [PubMed: 24018190]

(50). Wilson AA; Garcia A; Jin L; Houle S Radiotracer synthesis from [ $\left.{ }^{11} \mathrm{C}\right]$ iodomethane: a remarkable simple captive solvent method. Nucl. Med. Biol 2000, 27, 529-532. [PubMed: 11056365]

(51). Owen DR; Fan J; Campioli E; Venugopal S; Midzak A; Daly E; Harlay A; Issop L; Libri V; Kalogiannopoulou D; Oliver E; Gallego-Colon E; Colasanti A; Huson L; Rabiner EA; Suppiah P; Essagian C; Matthews PM; Papadopoulos V TSPO mutations in rats and a human polymorphism impair the rate of steroid synthesis. Biochem. J 2017, 474, 3985-3999. [PubMed: 29074640]

(52). Giannaccini G; Betti L; Palego L; Pirone A; Schmid L; Lanza M; Fabbrini L; Pelosini C; Maffe IM; Santini F; Pinchera A; Lucacchini A Serotonin transporter (SERT) and translocator protein (TSPO) expression in the obese ob/ob mouse. BMC Neurosci. [On line] 2011, 12: Article 18. http://www.biomedcentral.com/1471-2202/12/18.

(53). Chen M-K; Baidoo K; Verina T; Guilarte TR Peripheral benzodiazepine receptor imaging in CNS demyelination: functional implications of anatomical and cellular localization. Brain 2004, 127 , 1379-1392. [PubMed: 15069023]

(54). Ichiishi N; Brooks AF; Topczewski JJ; Rodnick ME; Sanford MS; Scott PJH Copper-catalyzed $\left[{ }^{18}\right.$ F]fluorination of (mesityl)(aryl)iodoniun salts. Org. Lett 2014, 16, 3224-3227. [PubMed: 24890658]

(55). Bielawski M; Malmgren J; Pardo LM; Wikmark Y; Olofsson B One-pot synthesis and applications of N-heteroaryl iodonium salts. ChemistryOpen 2014, 3, 19-22. [PubMed: 24688890]

(56). Bjurling P; Reineck R; Westerburg G; Gee AD; Sutcliffe J; Långström B Synthia, a compact radiochemistry system for automated production of radiopharmaceuticals, in Proceedings Sixth Workshop on Targetry and Target Chemistry (Link JM, Ruth TJ; Eds.) 1995 pp 282-284, TRIUMF, Vancouver.

(57). Smith DM Synthia gets extreme makeover courtesy of National Instruments, NIWeek08Worldwide Graphic System Design Conference, Austin, Texas, 2008; p 56.

(58). Clark JD; Baldwin RL; Bayne KA; Brown MJ; Gebhart GF; Gonder JC; Gwathmey JK; Keeling ME; Kohn DF; Robb JW; Smith OA; Steggerda J-AD; VandeBer JL Guide for the Care and Use of Laboratory Animals, National Academy Press, Washington, DC.,1996.

(59). Motulsky H; Neubig R Analyzing radioligand binding data. Curr. Protoc. Neurosci 2002, 19, Ch. 7: Unit 7.5. DOI: 10.1002/0471142301.ns0705s19.

(60). Costa B; Da Pozzo E; Giacomelli C; Barresi E; Taliani S; Da Settimo F; Martini C TSPO ligand residence time: a new parameter to predict compound neurosteroidogenic efficacy. Sci. Rep 2016, 6, 18164. [PubMed: 26750656]

(61). Costa B; Da Pozzo E; Giacomelli C; Taliani S; Bendinelli S; Barresi E; Da Settimo F; Martini C TSPO ligand residence time influences human glioblastoma multiforme cell death/life balance. Apoptosis 2015, 20, 383-398. [PubMed: 25413799]

(62). Cheng Y; Prusoff WH Relationship between the inhibition constant $\left(K_{I}\right)$ and the concentration of inhibitor which causes $50 \%$ inhibition $\left(I_{50}\right)$ of an enzymatic reaction. Biochem. Pharmacol 1973 , 22, 3099-3108. [PubMed: 4202581]

(63). Christman DR; Finn RD; Karlström K; Wolf AP The production of ultra high specific activity ${ }^{11} \mathrm{C}$-labeled hydrogen cyanide, carbon dioxide, carbon monoxide and methane via the ${ }^{14} \mathrm{~N}(\mathrm{p}, a){ }^{11} \mathrm{C}$ reaction. Int. J. Appl. Radiat. Isot 1975, 26, 435-442.

(64). Larsen P; Ulin J; Dahlström K; Jensen M Synthesis of $\left[{ }^{11} \mathrm{C}\right]$ iodomethane by iodination of $\left[{ }^{11}\right.$ C]methane. Appl. Radiat. Isot 1997, 48, 153-157.

(65). Lazarova N; Simćon FG; Musachio JL; Lu SY; Pike VW Integration of a microwave reactor with Synthia to provide a fully automated radiofluorination module. J. Labelled Compd. Radiopharm 2007, 50, 463-465.

(66). Gandelman MS; Baldwin RM; Zoghbi SS; Zea-Ponce Y; Innis RB Evaluation of ultrafiltration for the free-fraction detection of single photon emission computed tomography (SPECT) radiotracers: $\beta$-CIT, IBF, and iomazenil. J. Pharm. Sci 1994, 83, 1014-1019. [PubMed: 7965658] 
<smiles>CC[C@H](C)N(C)C(=O)c1cc2ccccc2c(-c2ccccc2Cl)n1</smiles>

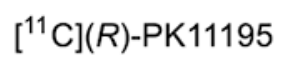<smiles>COc1ccc(OC)c(CN(C(=O)C[18F])c2ccccc2Oc2ccccc2)c1</smiles>

$\left[{ }^{18} \mathrm{~F}\right] \mathrm{FBR}$<smiles>COc1ccccc1CN(C(C)=O)c1ccccc1Oc1ccccc1</smiles>

$\left[{ }^{11} \mathrm{C}\right] \mathrm{PBR} 28$<smiles>CC(=O)N(Cc1ccccc1OCCC(F)F)c1cnccc1Oc1ccccc1</smiles>

$\left[{ }^{18}\right.$ F]FEPPA<smiles>CCN(CC)C(=O)Cc1c(-c2ccc(O[13CH3])cc2)nn2c(C)cc(C)nc12</smiles>

$\left[{ }^{11}\right.$ C]DPA-713<smiles>CC[C@H](C)N(C)C(=O)c1nc(-c2ccccc2Cl)c2ccccc2n1</smiles>

$\left[{ }^{11} \mathrm{C}\right] \mathrm{ER} 176$

Figure 1.

Structures of prominent first- and second-generation TSPO PET radioligands. 

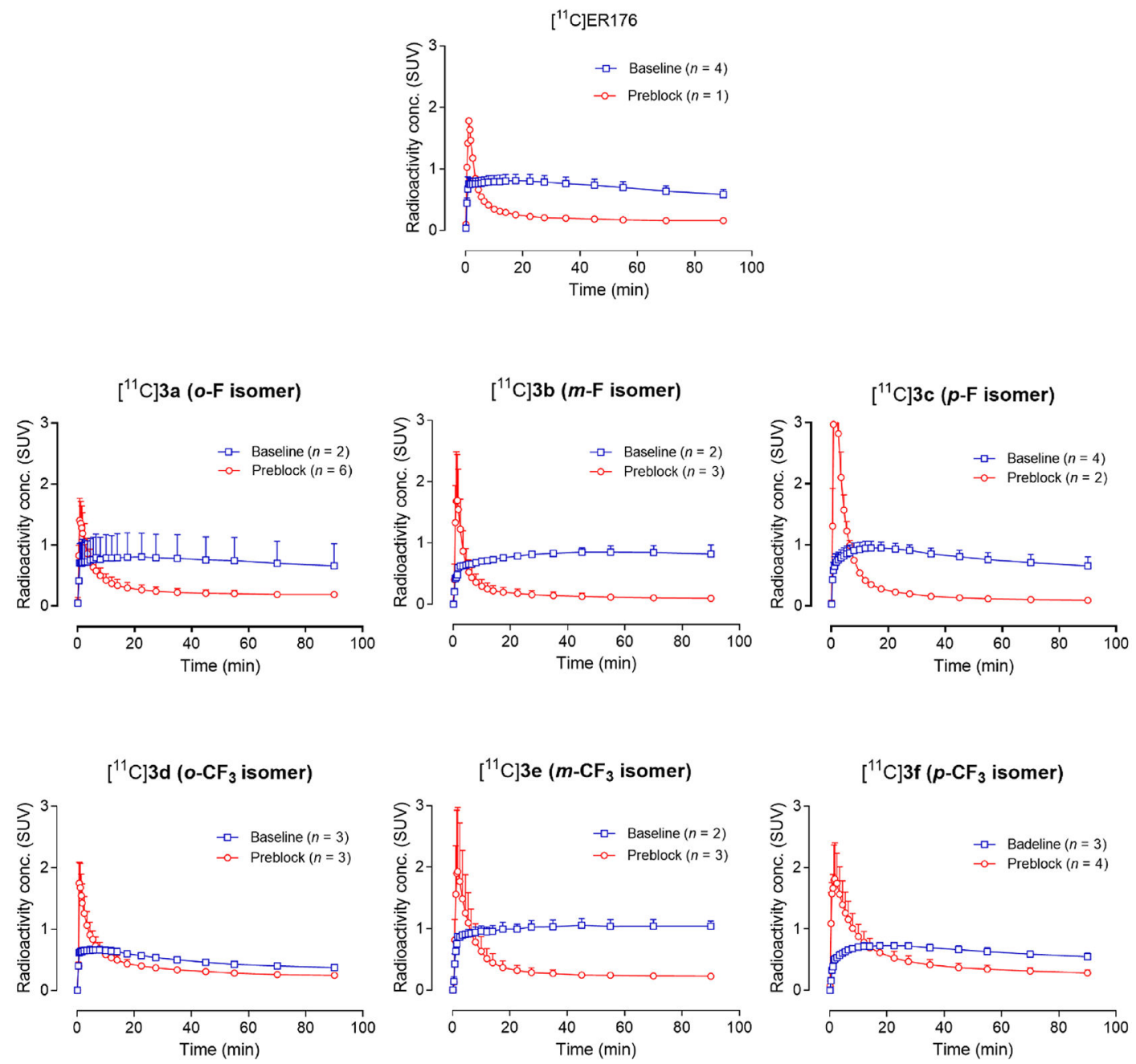

Figure 2.

Mean brain time-activity curves for each of the radioligands $\left[{ }^{11} \mathrm{C}\right] \mathbf{3 a}-\left[{ }^{11} \mathrm{C}\right] \mathbf{3 f}$ and $\left[{ }^{11} \mathrm{C}\right]$ ER 176 in mice at baseline and after blocking of TSPO with PK11195 at $5 \mathrm{mg} / \mathrm{kg}$ i.v. Error bars are S.D. values for $n \geq 3$ or half range for $n=2$ and are within symbol size if not shown. 


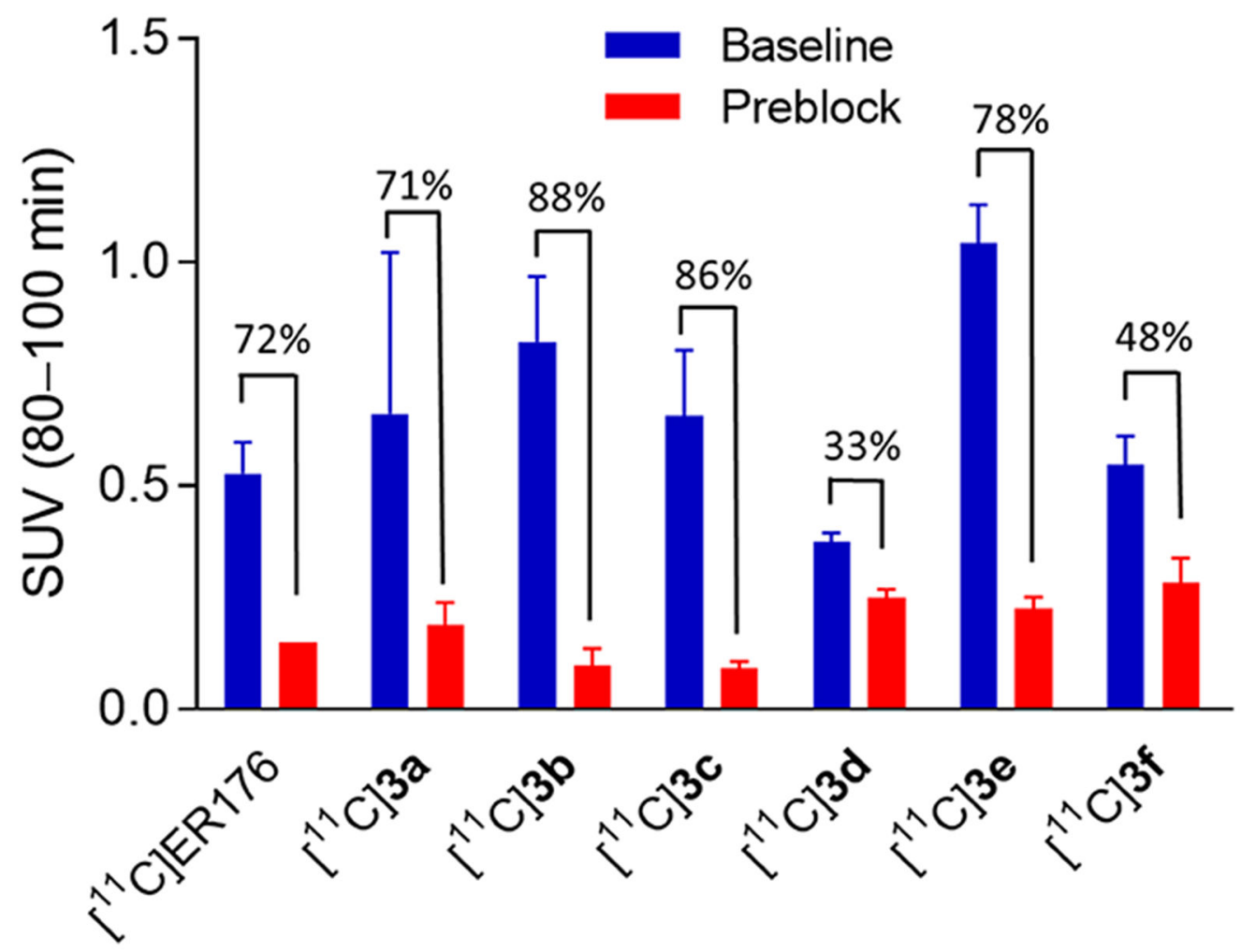

Figure 3.

Blocking effect (\%) of PK11195 (5 mg/kg, i.v.), as indicated by the mean difference of mouse brain uptake in the last $20 \mathrm{~min}$ (80-100 $\mathrm{min}$ ), between baseline and TSPOpreblocked conditions. Error bars are S.D. values for $n \geq 3$ or half range for $n=2$. 
A

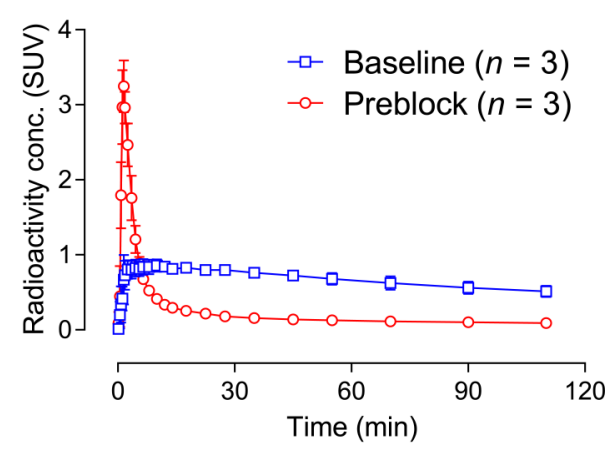

B

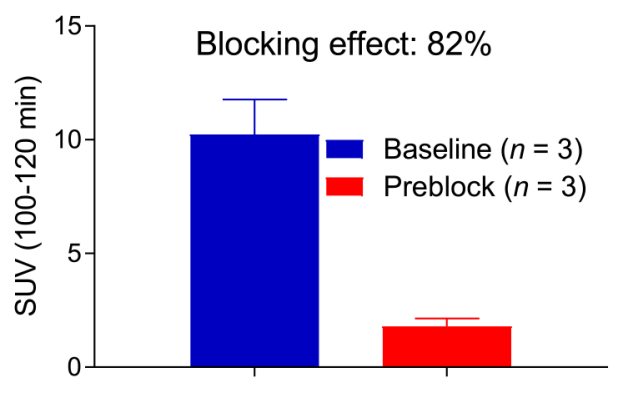

Figure 4.

PET imaging with $\left[{ }^{18} \mathrm{~F}\right] 3 \mathbf{b}$ in mice. (A) Mean baseline and TSPO blocked (with PK11195 at $5 \mathrm{mg} / \mathrm{kg}$, i.v.) brain time-activity curves. (B) Blocking effect (\%) of PK11195 (5 mg/kg, i.v.) as indicated by the mean difference between baseline and blocked conditions for brain radioactivity concentrations in the last $20 \mathrm{~min}$ (100-120 $\mathrm{min}$ ) after intravenous injections of $\left[{ }^{18} \mathrm{~F}\right] 3 \mathrm{~b}$. Error bars are the S.D. value and are within symbol size if not showing. 
A

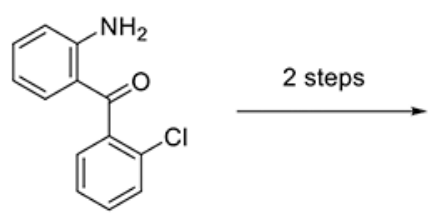<smiles>O=C(O)c1nc(-c2ccccc2Cl)c2ccccc2n1</smiles>

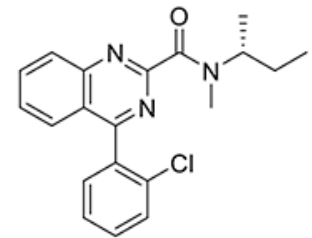

ER176

B
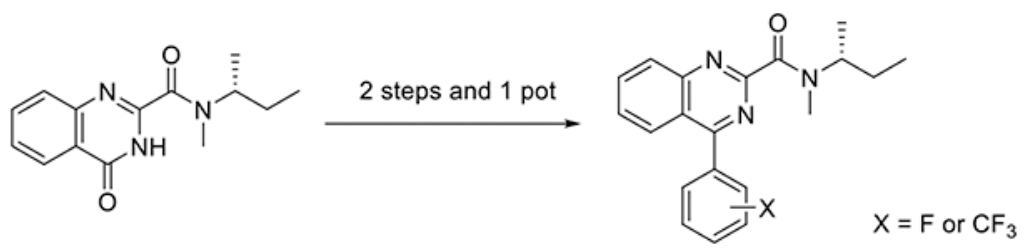

Scheme 1.

Original Pathway for Preparing ER176 (A) and a New Pathway for Preparing FluorineContaining 4-Phenylquinazoline-2-carboxamides as Ligands for TSPO (B) 


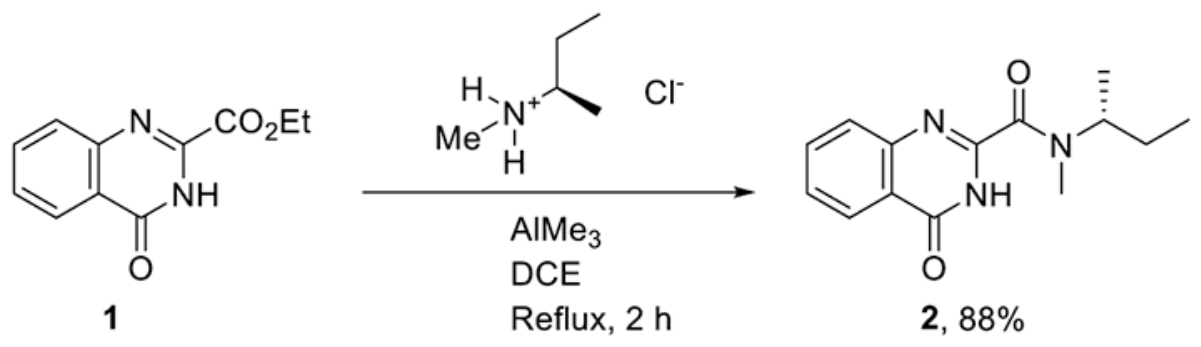

1) PyBroP

$\mathrm{Et}_{3} \mathrm{~N}$ 1,4-Dioxane RT, $12 \mathrm{~h}$<smiles>[X]c1ccccc1-c1nc(C(=O)N(C)[C@H](C)CC)nc2ccccc12</smiles>

3a, $X=o-F, 75 \%$

3b, $X=m-F, 66 \%$

2)<smiles>BrC1=CC[X]=C=C1</smiles>

$\mathrm{Pd}\left(\mathrm{PPh}_{3}\right)_{2} \mathrm{Cl}_{2}$

3c, $X=p-F, 81 \%$

3d, $X=0-\mathrm{CF}_{3}, 75 \%$

3e, $\mathrm{X}=m-\mathrm{CF}_{3}, 75 \%$

$\mathrm{Na}_{2} \mathrm{CO}_{3}$

$\mathrm{H}_{2} \mathrm{O}$

$100{ }^{\circ} \mathrm{C}, 4 \mathrm{~h}$

3f, $\mathrm{X}=p-\mathrm{CF}_{3}, 69 \%$

Scheme 2.

Synthesis and Structures of TSPO ligands $3 \mathrm{a}-3 \mathrm{f}$ 
<smiles>CCOC(=O)c1nc2ccccc2c(=O)[nH]1</smiles>

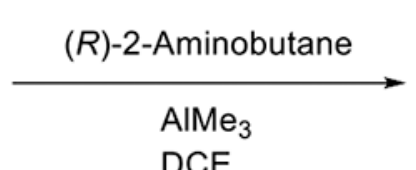
DCE

Reflux, $2 \mathrm{~h}$<smiles>CC[C@H](C)NC(=O)c1nc2ccccc2c(=O)[nH]1</smiles>

4, $88 \%$

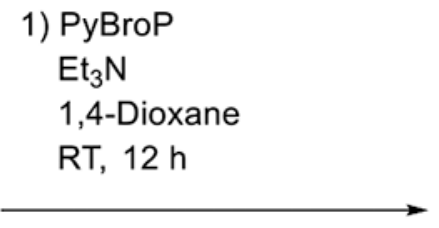

2)<smiles>[X]c1ccc(Br)cc1</smiles>

$\mathrm{Pd}\left(\mathrm{PPh}_{3}\right)_{2} \mathrm{Cl}$

$\mathrm{Na}_{2} \mathrm{CO}_{3}$

$\mathrm{H}_{2} \mathrm{O}$ $100{ }^{\circ} \mathrm{C}, 4 \mathrm{~h}$<smiles>[X]c1ccccc1-c1nc(C(=O)N[C@H](C)CC)nc2ccccc12</smiles>

5a, $\mathrm{X}=0-\mathrm{F}, 77 \%$

5b, $X=m-F, 85 \%$

5c, $\mathrm{X}=p-\mathrm{F}, 82 \%$

5d, $X=0-\mathrm{CF}_{3}, 65 \%$

5e, $\mathrm{X}=m-\mathrm{CF}_{3}, 78 \%$

5f, $\mathrm{X}=p-\mathrm{CF}_{3}, 89 \%$

Scheme 3.

Synthesis of $N$-Desmethyl Precursors, $5 \mathrm{a}-5 \mathrm{f}$, for Use in ${ }^{11} \mathrm{C}$-Labeling 


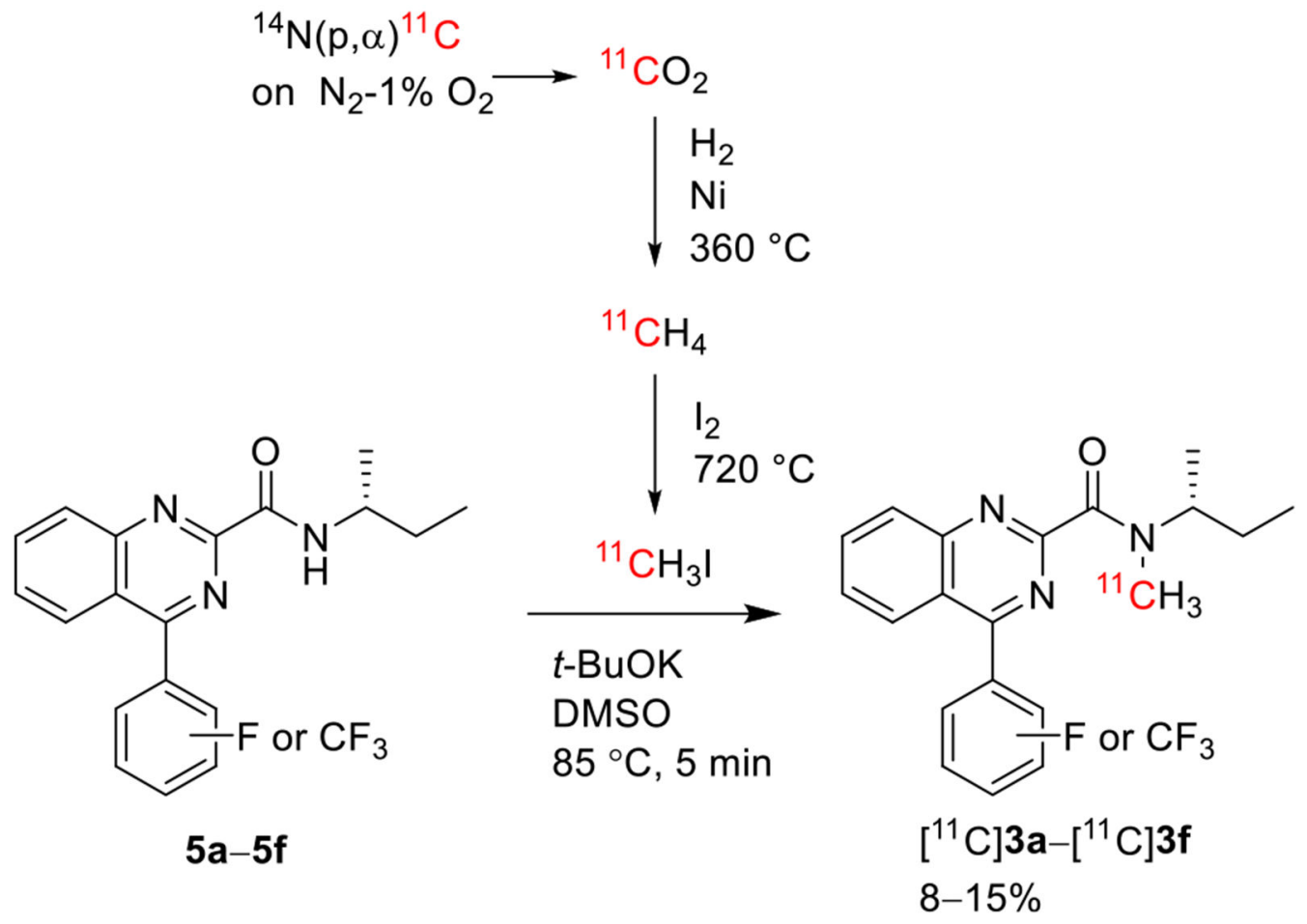

Scheme 4.

Radiosyntheses of Radioligands $\left[{ }^{11} \mathrm{C}\right] 3 \mathrm{a}-\left[{ }^{11} \mathrm{C}\right] 3 \mathrm{f}$ 
<smiles>CC[C@H](C)N(C)C(=O)c1nc2ccccc2c(=O)[nH]1</smiles>

1) PyBroP, $\mathrm{Et}_{3} \mathrm{~N}$ 1,4-Dioxane

$\mathrm{RT}, 12 \mathrm{~h}$
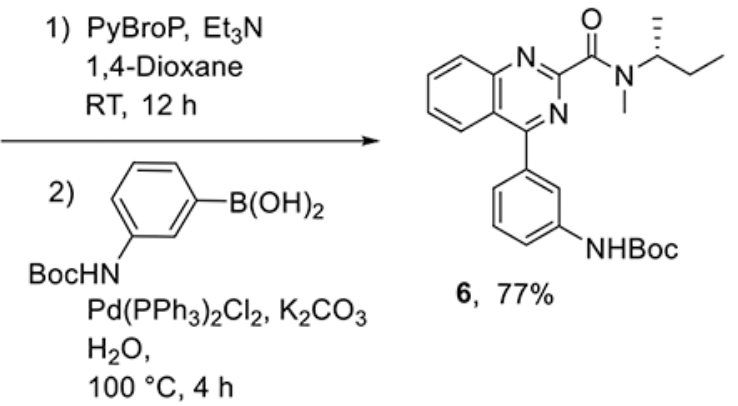

6, $77 \%$

$\mathrm{H}_{2} \mathrm{O}$,
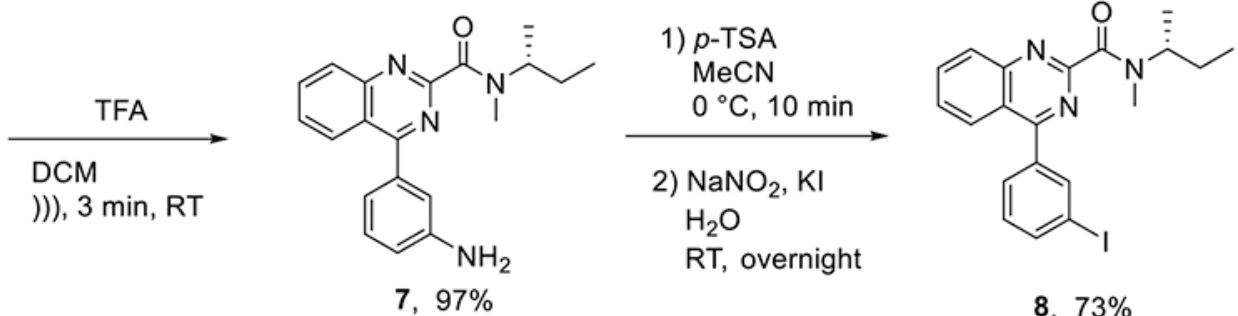

7, $97 \%$

8, $73 \%$
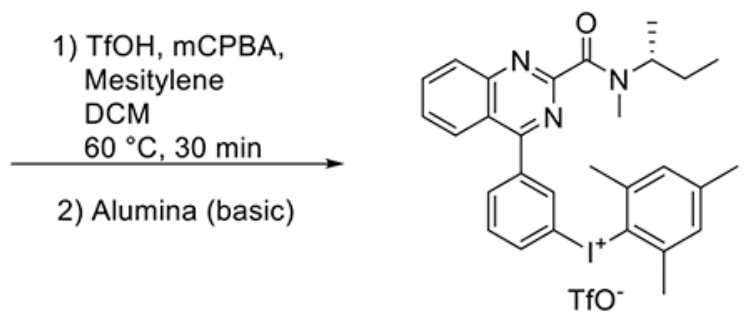

9, $41 \%$

Scheme 5.

Synthesis of Aryl(mesityl)iodonium Salt Precursor 9 for ${ }^{18} \mathrm{~F}$-Labeling of $3 \mathrm{~b}$ 


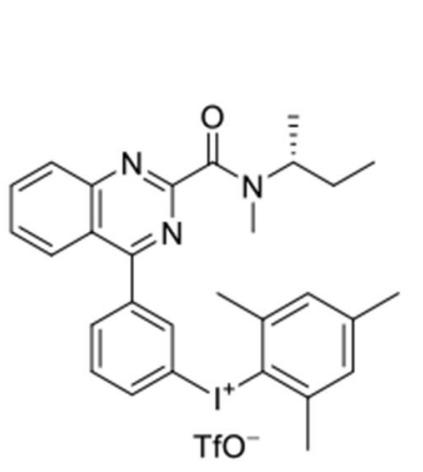

9

$$
\begin{aligned}
& { }^{18} \mathrm{O}(\mathrm{p}, \mathrm{n})^{18} \mathrm{~F} \\
& \text { on } \mathrm{H}_{2}{ }^{18} \mathrm{O}
\end{aligned}
$$

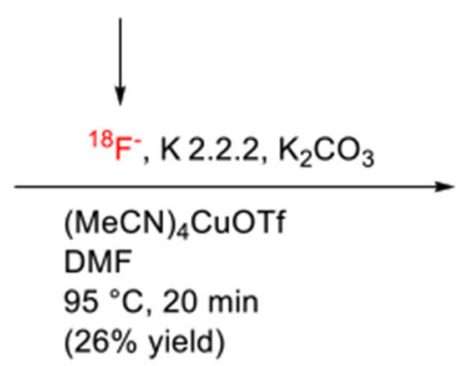

or

MW $90-100^{\circ} \mathrm{C}, 2 \times 90 \mathrm{~s}$

(51\% yield)<smiles>CC[C@H](C)N(C)C(=O)c1nc(-c2cccc(F)c2)c2ccccc2n1</smiles>

$\left[{ }^{18} \mathrm{~F}\right] 3 \mathrm{~b}$

Scheme 6.

Radiosynthesis of $\left[{ }^{18} \mathrm{~F}\right] 3 \mathrm{~b}$ 


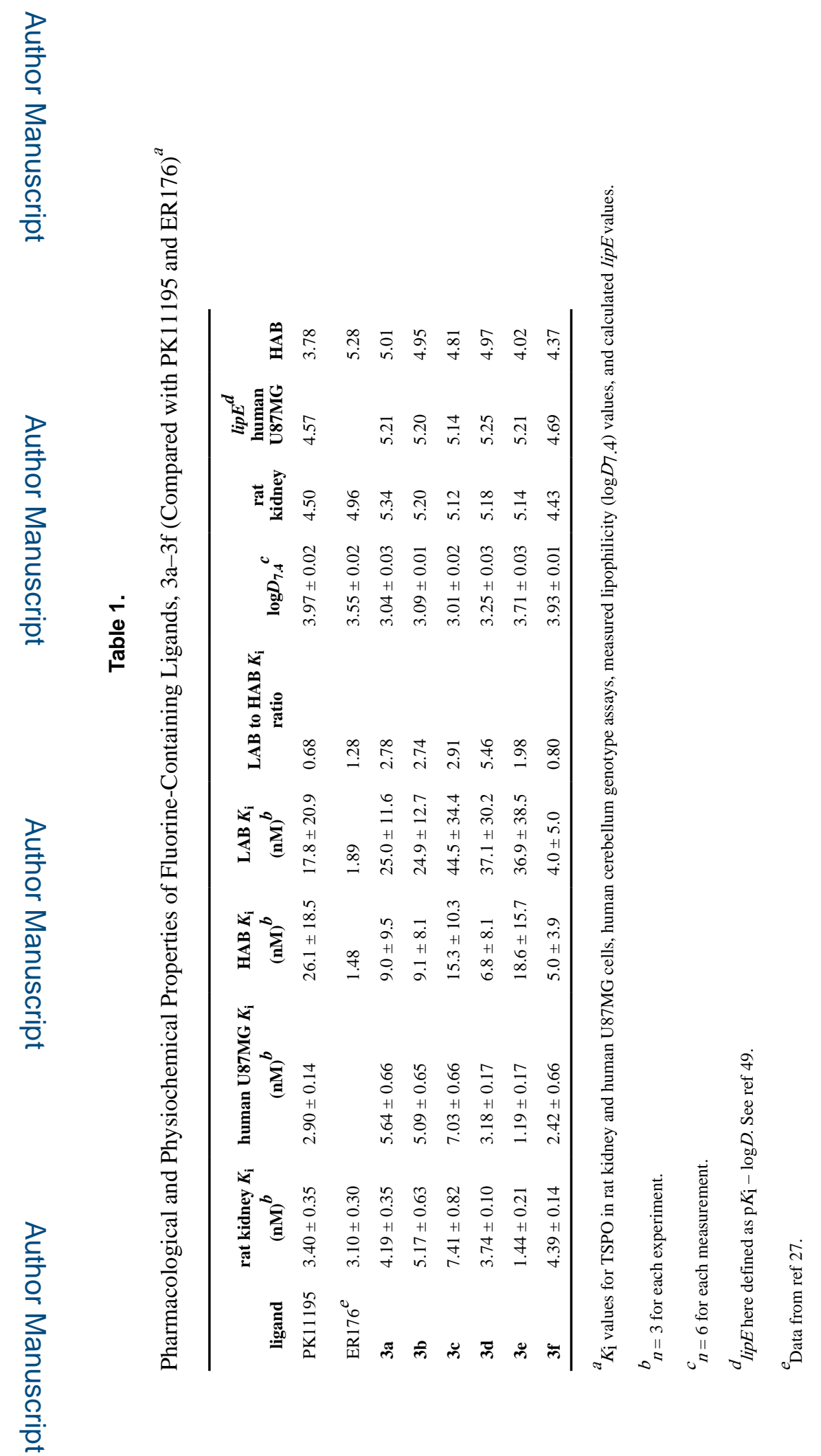

JMed Chem. Author manuscript; available in PMC 2022 February 05. 